\title{
REVISITS TO OLD HAUNTS
}

With Andrew Balan Pierce and Sufiet Erlita ${ }^{1}$

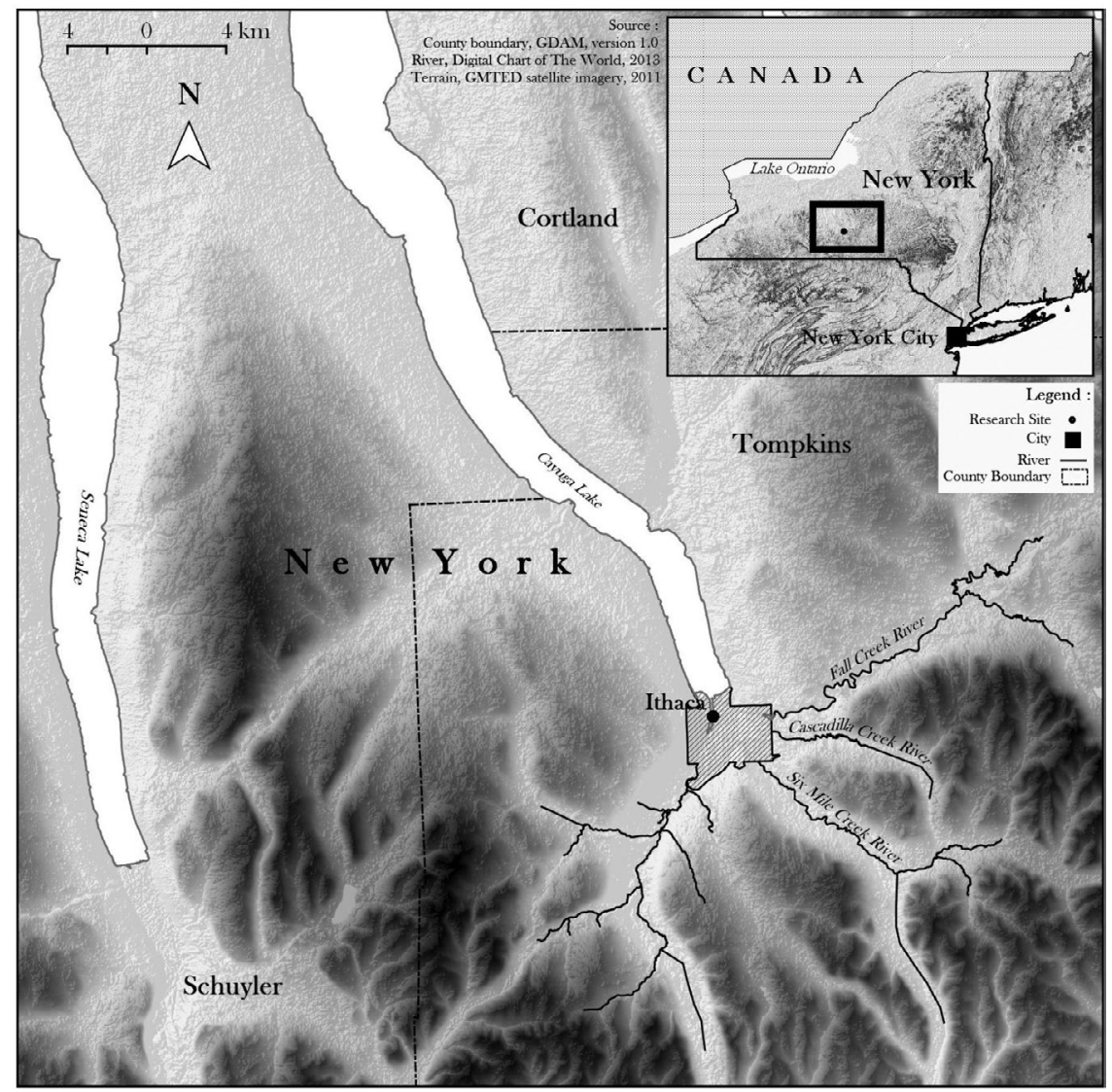

FIGURE 7.0: Map of Ithaca 


\section{Introduction}

This chapter focuses on masculinities in the recent and current world. I begin with a return to the reflexive element begun in Chapter 2, because of the particular difficulty - as discussed previously_of providing comparatively objective assessments about gender when one is inevitably enmeshed in one's own gender system. Thinking we can differentiate genuine transformations in a particular community from more global changes that affect that community or transformations in the researcher's perspective due to age and experience is a chimera. The best we can do is be clear about our own perspective and experience.

I then turn to what I observed in May to June 2017 in Bushler Bay, the onetime American logging community (Chapter 3). That discussion is followed by similar observations in the two Indonesian villages of Long Segar and Long Anai (East Kalimantan), in March 2019 (Chapter 4). I make a few observations about conditions in Sitiung, West Sumatra, based on work organized by Dr. Ardi from Andalas University in Padang. These are followed by brief concluding remarks, expanded in Chapter 8.

\section{Reflexive ruminations on American and global masculinities in 2019}

Gender systems have changed markedly since the 1970s. At the global level, there have been regular international conferences, policies and action plans since 1975, raising gender's visibility and supporting more equitable relations between men and women. ${ }^{2}$

In the US, though the current political climate includes considerable 'backward motion', there have been great strides forward in terms of gender equality over my lifetime:

- Women's reproductive rights were reinforced by legal precedents (e.g., Roe vs. Wade, 1973).

- Birth control became widely available (e.g., via Planned Parenthood, commercial markets, sex education in schools and better medical advice to patients).

- Women's sports opportunities were greatly expanded through Title IX ${ }^{3}$ (enacted in 1972).

- Women's involvement in formal employment increased and became more socially acceptable.

In all these changes, however, the emphasis was on women as 'the disadvantaged'. These changes also have had implications for men, manhood and masculinities. Thinking in terms of conventional men's roles, smaller families have meant lower levels of required responsibility for men as providers, which can be seen in a positive light or, more negatively, as a reduction in men's importance 
(seen in some examples from global GENNOVATE studies; Elias et al. 2018). Women in sports requires a rethinking of the meaning of sports as a symbol of masculinity among many groups, as a mechanism by which physically talented men gain prominence over others (e.g., Anderson 2009 or Connell 1995). Similarly, women in the labour force have required men to adapt, to face challenges (whether explicit or implicit) to their earlier roles, often as sole provider for the family (e.g., Reed 2003, on men and women in Canadian logging communities; or Petesch et al. 2018, for sub-Saharan Africa).

Here, I shift from these broader societal changes to the changes I've experienced in my own relations with men, looking at specific relationships and the contexts in which they have played out. Besides providing a glimpse into my own biases and assumptions, these patterns are not atypical of middle-class, American, highly educated, white couples in university neighbourhoods (in this case, Cornell University). Clearly not representative of American life at large, these patterns nicely represent the population likely to be active in international circles, including those that pertain to forest-related policymaking (see Nader 1972, for a dated but still timely perspective on the need to 'study up').

My husband, Dudley, has provided my most intimate current knowledge of American masculinity. We married in 1985 (in Sitiung); he is of middle-class background and has a PhD in fisheries biology. Like my first husband (see Chapter 2), Dudley is from the American Northeast and has been supportive of my professional aspirations and passions. I have also worked collaboratively with him on professional projects.

He fulfills a number of conventional ideals of American masculinity. He is (or was-like me, he shrank a bit) six feet tall, attractive, was good at sports before knee problems prohibited that activity, knows a lot about fixing things around the house (indeed, likes to) and is the 'strong, silent type', tending to keep his feelings to himself (sometimes unaware of them). He was the main provider in his previous marriage. He was an early student of computer languages (substituting one of those for the language requirement in grad school!), has always been good at math and science and values logic and knowledge highly.

On the other hand, he knows how to cook (though I cook most meals) and occasionally enjoys it, willingly performs various household tasks and has fairly cheerfully been a 'trailing spouse' for most of our married life. When I offered periodically to leave the job I loved, he consistently declined, expressing his appreciation of the intense work involved in periodic consulting and the full-time breaks between assignments. He also recognized the value of my comparatively secure employment and sufficient income. In his retirement, he is a gardener, a sailor, a photographer and an eternally curious individual. Like me, he is peripherally associated with Cornell University (as an 'adjunct associate professor'-a somewhat more prestigious title than mine, 'visiting scholar').

Although I believe he feels comfortable in his masculinity, I don't believe that it is of central concern to him (though perhaps it was when he was younger?). I have not seen him trying assertively to demonstrate it, as some men do; nor 
have I seen him responding defensively to what might be perceived as threats to it; he is more likely to give a dismissive snort. The fact that he has not been the primary provider in our marriage occasioned periodic disapproval from his mother in the early years. Once in the 1980s when I mentioned to her my view that when a husband and wife were both employed the domestic tasks should be split, she responded with shock and dismay, 'You don't expect him to do housework, do you!?'. She would also sometimes express her feeling that he should 'get a real job'.

Although never to my knowledge subjected to the snide harassment my former husband experienced in Bushler Bay, Dudley was irritated sometimes by my FRI co-workers, a few of whom seemed to dismiss his inputs because he was a spouse rather than an employee (even when he was occasionally working as a consultant there). But I saw no evidence that he took it to heart as some men would. The degree to which this is a personal trait or a change in both the general atmosphere and a personal adaptation to that remains a question.

$\mathrm{He}$ is interested in and enjoys sexuality, but if it is a defining feature of his masculinity (as it was for my previous husband), that is not clear to me. Nor is his enjoyment of sports. He watches football every fall, enjoying particularly the links with the University of Georgia, where he worked for eight years before I knew him. But when we lived overseas and could not watch it, he did not seem to suffer (unlike my father) $;{ }^{4}$ nor does he watch any other sports except soccer World Cups (both men and women). He is not violent, and has never beat me, my children or anyone else, to the best of my knowledge.

We have a 'companionate marriage', with what has evolved to be ironically a somewhat traditional division of labour: ${ }^{5}$ I now cook, shop, wash dishes and clothes, occasionally dust surfaces and clean two of the bathrooms. He does the floors, windows, supplementary cleaning in the kitchen and bathrooms and takes complete charge of our three acres of land - the vegetable garden and most of the flower garden, organizing mowing and some snow clearance, reducing invasive species and doing virtually all outdoor tasks. He also takes care of his own needs during the three months of the year that I am away caring for my aged mother. ${ }^{6}$ Why the somewhat traditional division? Most simply, because we have gendered expertise gained during our youths, combined with his greater physical strength, required for some of these tasks. The other couples our age whom I know well show similar tendencies: attempts to ensure gender equity, but in some cases lack of the knowledge, experience and physical strength (and perhaps the motivation) necessary to totally shift traditional tasks. As upper-middle-class women, many hire someone to do the heavy house cleaning tasks (floors, bathroom cleaning, windows, yard work) typically organized by the woman. ${ }^{7}$

The masculine harp strings that characterize the older men I know well include breadwinner, father/grandfather, fixer of household equipment, manager of vehicles and heavy equipment, caretaker and mathematics (in the form of taxes, bill paying, etc.). But I see a much wider spectrum of publicly acceptable and visible gender arrangements now vis-à-vis most of the 20th century. 


\section{BOX 7.1 SEXUALITY AMONG THE AGED-RUMINA- TIONS FROM ITHACA}

I was driving home on New Year's Eve, from dropping off my husband's walker and the ice machine we'd borrowed to use during his knee replacement (which had morphed into a heart attack) from the Finger Lakes Independent Living Center a month before. Stopping at a red light, I found myself next to a Kenworth truck. Looking up from my tiny Prius at the huge vehicle beside me, I was transported briefly back to my time in Bushler Bay, flooded with the memory of my own passion (now so dimmed). The big truck loomed over me, symbolic of a certain kind of in-your-face masculinity, which I'd found embarrassingly attractive in my youth, and still somehow remained attracted to, despite my intellectual recognition of its toxic elements. Such symbolism works through the emotions, not the intellect.

Changing gender roles and ideals appear even more obvious among younger, educated couples. Some marry, some don't. Some are heterosexual, some are not. Some follow traditional gender roles in their households; some switch roles; others create unique patterns based on personal and shared preferences. Occasionally husbands stay home and take care of children while women go out and work. One such employed wife mentioned her theory that some women who stay at home with their children look at childcare as a kind of profession, striving for 'success' in much the same way that formal workers may. When I recounted this theory-which I also found believable - to a stay-at-home dad, he agreed that he felt that way about fatherhood.

The fathers who stayed home though felt some dis-ease about not being the breadwinner; two expressed the view that if they were to continue emphasizing fatherhood in this way, they would likely be subject to more pressure from extended family members to return to breadwinning. In general, all those I know well - men and women - strive to be egalitarian in their division of labour.

I do not mean to suggest that American marriage has become entirely or uniformly equal. I live (we all live) in clusters of people who share many traits (such as the relatively elite 'island' that is Cornell University), and I know there are strong trends about in America (some in the rural world encompassing my university), trends that encourage stricter gender dimorphism, celebrate traditional gender roles and decry egalitarianism and inclusivity-symbolized by current President Trump.

Turning to my four children, the oldest (born in 1969) did not complete college and is in a somewhat conventional marriage, with her husband as wage earner and she a homemaker (a role she sought). She has taken on motherhood as a profession and both she and her husband have strong voices in household 
decision-making. Her husband plucks the breadwinning, fatherhood and sports harp strings most consistently_ spending his free time coaching the mainly boys' hockey team, for which one of his daughters is goalie; he rarely does any housework, beyond cooking an occasional meal.

Our other three children approach domestic tasks more equitably than would have been common in my youth. One son ( $\mathrm{PhD}$ in history) works as an international intelligence analyst, keeping him away from home 10-11 hours/day (>two hours/day commuting). When confronted with a choice, his job or hers (same degrees) in different states, they chose his. But he is actively involved in most household tasks, including childcare, insofar as his job allows-far more involved than would fathers have been in my youth. Fatherhood, caring and breadwinning are his harp strings most visible to me (though at work I believe he replicates many of those described in Chapter 6).

My other son has a BA and his wife, some college; they have no children yet. Both are of an entrepreneurial bent that combines business with the arts; they also share household and work tasks quite evenly-though they have recently lived in Indonesia, where household labour can be obtained inexpensively. ${ }^{8}$ I recall my now divorced daughter's description of their household division of labour: "I do the wet things, he does the dry". None of our children fully accepts the traditional American ideas about how marital relations and labour should be conducted/structured that I grew up with (and rejected).

With regard to older couples in the US, I offer what is basically a series of hypotheses based on my experience in rural Washington and New York ${ }^{9}$ states, and among my own relatives all over the country. Among the older, middle-class, American couples I know well, women seem to have gained authority, though also probably work harder vis-à-vis their husbands. ${ }^{10}$ The women are usually somewhat younger and tend to be in better health. Husbands, when they retire, enter a domain that has typically still been their wives' to manage, the household-a process that requires adaptation (e.g., Hatch 2000; or Varley and Blasco 2001, on urban Mexican men). At the same time, the broader context (mass media, education, policy) — both American and international-has been marked by increasingly serious attacks on male dominance and patriarchy as ideologies and institutions. Women, who have accepted some version of male dominance throughout their lives, are unlikely suddenly to change their long-established interaction patterns; but neither are they likely to accept their husbands' right to determine life as much as they may have in the past. The outcome seems to be-and again this is more a hypothesis than a 'finding' - a small take-over by the women, who now may drive, organize social events and express more independence than previously. When I've expressed this view, a couple of women have argued that it's always been like that, that it's not a change occurring in old age. Maybe.

\section{Observations from Bushler Bay in $2017^{11}$}

In 2016, I began planning a brief re-study in Bushler Bay (Figure 3.1). I had kept in good, mostly long-distance contact with the man I'd been sexually involved 
with in the 1970s (his wife had died a decade earlier and he had remarried). I became 'friends' on Facebook with several other friends from the 1970s. One coterie of these folks had been John Birch Society sympathizers (a right-wing political group) and are now avid Trump supporters. I've regularly exchanged conflicting political views with them, in my effort to understand their perspective (though I'm not sure it's helped much) - mostly after the fieldwork reported in this section. Many Bushler Bay residents, however, lean to the more 'progressive' end of the American political spectrum. ${ }^{12}$

Given the changes I'd seen in upstate New York, and my many years away from the US, I was excited to see how this once-familiar setting had changed. I made a quick, two-day trip in the spring of 2016, finding that superficially, it looked much the same: a tiny cluster of businesses around the school as the centre of town, a main highway running through it. I informally interviewed a few people, which whetted my appetite for more.

The study Hummel (an ecologist) and Cerveny (an anthropologist), both USFS employees, and I planned focused on women's involvement in forest management. They also wanted to test the potential of rapid rural appraisal (RRA) tools for use by the US Department of Agriculture's Forest Service (USFS) research branch (also the funding agency). I spent two weeks in Bushler Bay in May to June 2017 and tested six RRA tools as well as conducting what I call 'ethnography light' (an approach built on close and longstanding links with the communities). The tools tested included two pebble sorting tools (one on non-timber forest products and one on forest activities), the Who Counts Matrix, an interview guide, participatory mapping and future imaging, plus a conventional questionnaireall administered using pre-existing relationships, emerging opportunity and snowball sampling.

Several studies had been done in the area, in addition to my own. Informal harvest of forest products was and remains an important activity. Both communities were directly affected by the 1990s 'timber wars' (Bari 1994; Dark 1997). Since the near-demise of logging in the area, Olympic Peninsula counties have experienced higher unemployment and population decline along with changing identity (Kirschner 2010). Of the in-migrants, many are 'amenity migrants' ${ }^{13}$ The beauty of the area, its rainforests and beaches, remain a steady draw for visitors. The forests, which once supported the communities financially, are increasingly appreciated for scenery, heritage, outdoor recreation and tourism.

Driving into Bushler Bay in 2017, I was again struck by how little had changed. Besides the school, the small businesses and the highway, the USFS office remained on the way south out of town. Some of the residential areas near town were a little more dilapidated, but further out, there were some homes, much more luxurious than in earlier times. The population was a little lower these days (from 500 or 600 in the 1970s to 437 in 2015). As I dove into the research, I discovered that life was really quite different now.

One of my earliest experiences this time around was a run-in at the café, where loggers always used to assemble looking for the day's work: 
When I walked into Bushler Bay's cafe, Hubert ${ }^{14}$ was there (I don't know him, but he was dressed as a logger). I announced happily that I was coming back to Bushler Bay after 40 years and would be here for two weeks. He wanted to know my name, and I told him. He said "Oh, you're that woman. I hear you wrote some pretty bad things about Bushler Bay". I expressed surprise and asked if I could join him, and he said, "No", point-blank. Then I asked his name, and he said, "That's for me to know and you to find out". The waitress harassed him about being so rude, called him an asshole even. But it was clear they are friends. I explained that things were pretty bitter between the loggers and the Forest Service in those days and that we'd tried to reflect the feelings each group had for the other. He began to warm up a bit. He said, "The Forest Service folks, they always felt they were better than us, and that don't fly around here. Some of them were alright, but the higher-ups, they were the worst". He was also under the impression that the "Forest Service don't even replant anymore" [untrue]. Turns out he came here in the 1970s from Illinois, started out as a choker-setter and ran a lot of heavy equipment. He'd done almost all the logging jobs, but had multiple surgeries, at least some on his back. When I asked if he was retired, he said, "The state retired me. They got tired of paying for my operations". He also said, "Dan [a respected Local15 long-time logger] says 'they're killing our kids". (Not sure if 'they' refers to the USFS or the government or what). So I'm suspecting Dan may be the source of the story that we wrote bad things. I'm pretty sure Dan read the case study. ${ }^{16}$ So. . . getting words out of one-time loggers aint gonna be easy!

(notes, 23 May 2017)

Just got back from a trip to town, for a meal at the café. Learned that the Pecker ${ }^{17}$ Pole micro-brewery is in the back garage of the café. T-shirts with the Pecker Pole logo available for $\$ 20$.

(notes, 22 May 2017)

The interchange with Hubert reminded me of the challenges of doing fieldwork in this community, where privacy was so central. The second observation suggested that publicly, sexuality remained an appropriate topic, focused specifically on men's bodies (as in the 1970s). Hubert's comments represented a nice intro to several recurrent masculine harp strings — disdain for the 'chords' represented by the USFS (social hierarchy, concern about job security, indoor work), a strong value on independence and straight speaking, commitment to the danger and skills required in logging and its role as a key chord in Local Bushler Bay 'songs'.

The environmental pressures that had begun in the 1970s had continued, resulting in a halt to all public logging near the community. Some private logging continued. $^{18}$ But logging was no longer a primary source of the community's livelihood; only five loggers were said to remain. The conflict between loggers and the USFS had also dissipated. There were few USFS personnel still working 
there and the Washington State Shellfish Lab had closed down, both reducing the number of Public Employees. The source of internal conflict now, though reduced, was between the environmentalists and those earlier labelled Locals. In one interview with a community leader (an in-migrating man), he

began by saying that the community was divided in two between the 'older pioneers, lumberjacks' who remember a time when there was lots of work, three gas stations. Enter the spotted owl. ${ }^{19}$ One of his neighbours' father went to the mill, ${ }^{20}$ was laid off, and came home and blew his brains out.

The other half is what are termed 'environmentalists' or 'tree huggers'. The two groups have nothing to do with each other. Won't work together. But the lumberjacks are dying off and environmentalists are increasing, so they will 'win', he said.

(notes, 25 May 2017)

Another key change was a simple demographic one. Whereas in the 1970s, the age distribution had been a fairly normal pyramid (with $12 \%$ of the county over 60), now between 31\% (Bushler Bay proper) and 48\% (the nearby Hood $\mathrm{View}^{21}$ hamlet) were in that age range. Many of these elders are in-migrants from urban areas across Puget Sound and elsewhere. These facts have meant a huge reduction in the significance of the breadwinner harp string: few jobs available and many people past working age.

In the survey we conducted at the Hood View shrimp festival $(n=21$, diverse ages), we asked "What kinds of things do you do in the woods for income?". Of those who answered, $38 \%$ of the women and $63 \%$ of the men reported no forestrelated income, whereas $24 \%$ of women reported some (related to tourism, an environmental NGO and as a stimulus to creativity). The only men reporting any such income were $13 \%$ who reported having previously planted trees. A quarter of men and women left the question blank, which may have meant they also gained no income from the forest.

Looking at gender, the most dramatic change was the reduction in its apparent significance as a differentiating social structural feature. The clubs in the community, previously strictly gender-segregated, are now integrated. The Who Counts Matrix ${ }^{22}$ strove to distinguish the importance of men and women for forest management on seven dimensions. The dimensions ${ }^{23}$ were assessed on a scale of 1 (high relevance for forest management) to 3 (low relevance). On average (means), for Retirees (2.2) and Locals (1.3), men and women's scores were the same, and for Public Employee women and men there was only a 0.2 difference (2.0 to 1.8 , respectively), with men considered to 'count' slightly more. The biggest difference was for 'pre-existing rights', which were considered greater (lower number) for men than for women, across the board.

The pebble distribution methods confirmed both the reduction in gender differentiation and the diminution of importance for logging. Thirteen activities 
(previously determined to be of relevance in the region) were assessed by 23 , mostly elderly people, ${ }^{24}$ distributing 100 pebbles among the activities. Had we used such a tool in previous times, logging would surely have gotten a very high proportion of the pebbles, leaving only a few for the other activities. However, the 2017 results were fairly evenly divided among activities, with six activities getting exactly the same assessment for men and women. With the exception of logging, for which women were allotted 1.5 pebbles to men's 4 , and hunting (2.5 for women, 5 for men), no other activities were differentiated gender-wise by more than 1 pebble (or 1\%). The harp strings associating men with logging and with outdoor activity remain, but are seriously eroded, especially if seen as contrasting with women's involvement (a one-time reinforcement of masculine dominance).

The pebble distribution tool on non-timber forest products, which assessed men's and women's involvement in only seven categories, ${ }^{25}$ showed more gender differentiation, but men and women were both involved in collection of all the products. The average allotment of pebbles was 7.1 per category, with men averaging 8.3 and women, 5.9. As with activities, these differentiations are not extreme, suggesting a lack of significance in terms of masculine harp strings - or perhaps a trend toward the muting of gender difference. A question remains in my own mind as to whether these findings derive from the elderly sample (some have argued that gender differentiation reduces in old age ${ }^{26}$ or from the broader societal reduction in emphasis on gender differentiation.

To examine the current manifestation of the harp strings that were important in earlier years, we turn to participant observation and the rich interview data (interview dates, given below, once for each man, apply to all associated quotes). Here I recount the varied stories of three men: one a Local man (whom I'll call Tom), who has adapted to the economic changes and who retains a quite traditional view of gender roles, with 'modern' variations; one a working in-migrant (Dick), with a lifelong history of visiting the area before moving there; and another native son (Harry), who is now seriously handicapped and semi-retired.

Tom, of middle age, comes from a very religious natal family in which his father ruled the roost. ${ }^{27}$ The family was poor and the father worked long, difficult hours logging to make ends meet. Tom and his brother, on the other hand, feel able to make more money with fewer hours and easier work.

Each owns two homes, gets up late and is better off than their dad. Both of their "wives are happy with a credit card, plenty of gas, a working car". His wife could go help [a relative] in another town, she could afford to do it. ${ }^{28}$

(notes, 29 May 2017)

There was a clear element of competition between sons and their father.

Tom expresses his belief in and practice of traditional gender roles. He says, "I think of myself as the provider-protector of my family"-two conventional masculine harp strings expressly emphasized several times. He sees men and 
women as having different, but complementary natures: The man manages (and presumably controls): "I handle all the money, administer the household, have the keys to the post office". But in the same breath, he acknowledges that this is a "lost lifestyle in the modern world". He also emphasizes that his role and his wife's are of equal importance.

"Women are inherently better caretakers, sometimes to a fault. I live in a traditional family. I say we have two incomes; I have both the jobs. My wife is a wonderful wonderful wonderful person. She is raising the kids."

He feels he's the protector/provider for his wife. But, he says, it's not a lopsided relationship. He respects his wife. On the balance sheet, he provides the money, and she provides a wonderful home. Their work is of equal value.

He reminds me that he's not a logger, but that he's able to use his logging skills (from previous days) in his successful company. He has "felled trees professionally, driven a log truck, loading, lots of logging jobs in earlier times". He says, "Men want to be respected, to feel strong; the logger and outdoorsman are still important ideals here. Even when we're old, men want to be strong".

His interest in fatherhood and, even stronger interest in being a protector, come out in several statements. Where his wife likes "the idea of a wolf howling in the distance", he would prefer to get rid of wolves, focusing on the dangers they represent. He remembers one tearing a beloved dog to shreds. He feels his wife doesn't realize the danger they pose.

His emphasis on rationality is evident from several of his comments. He interprets his maintaining an orchard where deer come to browse as "chumming for cougars and coyotes". He says he hunts deer partly to reduce this population that draws bears and cougars into his terrain. Elsewhere, he emphasizes the importance of balance, between men and women, in extraction vs. protection of forests, in the economy:

In the '50s and '60s, even the 1970s, a logging company would have two timber fallers on one tree, two skidders at the landing, two equipment operators-8-12 people grouped on a landing. Six loads of trees might go out. Now it's so mechanized that you only need three guys in the forest doing 25-30 loads a day. So, it only supports three families (with the wife working too). Balance is way off.

Tom told a story of one Local family who owned "thousands of acres of forest land". When the owner died without a will, one of his sons assumed that land would go to him as "the only remaining logger, the only one who knew what to do with the land. Loggers don't recognize any other uses". Tom feels that forest lands belong to all the people. "An Indian in Oklahoma also owns this National Forest". 
Another significant contrasting aspect of Tom's masculinity, vis-à-vis earlier and more antagonistic Bushler Bay versions, is his attitude about homosexuality:

In the 1970s there were no social media, less info, just evening news. Every man was struggling to be manly. There was no recognition or tolerance for any other way of being. Now, we know that there are 1000s of gay boys out there, so now there is acceptance. If I was gay, I'd have a boyfriend or husband. When I was a kid, if someone even wanted to be a chef, he was shunned or would have been.

Tom also captures Local symbolism reflecting the differentiation between environmentalists (which are lumped with tourists) and loggers-in their preferred kinds of vehicles. Ford F150s, seen as masculine, ${ }^{29}$ are preferred by loggers, whereas tourists and environmentalists are seen to prefer Subarus. Subarus are less symbolic of gender, more a set of values and lifestyle, except as distinct from the clearly masculine Ford F150s.

[Tom] went to the Army . . . and came back in 1995. No stick of Federal Forest was being cut. Only one [forest] thinning sale on Rocky Brook. People [loggers] would build roads to get the trees they cut and they'd maintain them ("for tourists, granola crunchers [environmentalists] and fire suppression"). "Look at the cars: Subarus outnumber F150s 20-1 in the woods". He wants me to go up to Scar Pass and count, or count the cars headed for Hood Canal bridge to see both the kinds and the number. Sometimes they are backed up to Center Road [ca 18 miles], he said. And this traffic has nothing to do with rock quarrying or logging.

Dick, our second example, is a middle-aged in-migrant from one of Puget Sound's cities, with lifelong links to his property, some distance from Bushler Bay proper (notes, 24 May 2017). ${ }^{30}$

I drove for 25 minutes to get to his house, which is beautifully located on [the water], on the [... . Peninsula. I drove through lovely forests, lining the road part of the way, saw entrancing views of the Olympic Mountains from time to time, as I went by a clear cut; I found him down by the water, [in a beautiful home] down a gravel path, surrounded by forest.

His first words emphasized the changes he'd seen in the local economy: from one based on logging to one based on recreation, including many 'amenity migrants'.

Logging used to be active. Logging roads were for timber. Now the area is managed for recreation. The Forest Service used to employ a lot of people, now not so. He remembers when he first saw a clearcut and could see the Olympic range. Now they are all up and down the peninsula on 
DNR [Washington State Department of Natural Resources] land. But he watched it grow back. So clearcuts don't really bother him. It will grow back, he's seen it. He's just glad it's not a bunch of houses.

Like Tom, Dick has close ties with his extended family, who share ownership of 40 acres in the immediate area, which had belonged to his grandparents. His love of the forest comes out clearly. Compared to Tom, Dick's sense of his own masculinity is muted. He stressed the importance of management of the forest, of his reliance on government agencies to ensure its sustainability-which implied no antagonism to hierarchy, despite running his own business. Although he recognized the need and legitimacy of logging, he also expressed suspicion about private management, having seen others buy land and promptly denude it, in one case that particularly disgusted him, to buy a motor home.

"People need to remember how long it takes, he said. It would take over 100 years to grow back. It's a 50-60-year cycle for the DNR. The peninsula was logged around 130 years ago". He saw evidence of the logging, including pegs (or was it notches?) in the stumps (used for the men to stand on when cutting with a cross cut saw) and a logging camp a mile or so up the peninsula from his place.

Dick's relationship with his wife was also markedly different from Tom's. His responses to my questioning what sorts of things he did in the forest follow:

He hikes, lives in it, gardens, recreates, gets his wood (heating source, which he cuts and his wife splits), drives through it to work, runs on logging roads (to avoid cars), rides his mountain bike, walks the dog, picks mushrooms for food.

He said that his wife does the same things he does in the forest, but she's more sensitive about the remaining trees. He said, "We do everything together. She's my companion and I wanted to introduce her to the things I enjoy". They also ski and climb in the forest-though now he says, he just works. He has [several] employees and business has been booming for the last ten years.

When explaining the maintenance of their widely admired and beautiful garden, their shared experience of caring for it was clear. His parting comment as I left, "I tried to tap my feminine side", reminded me of the cases described by Connell (1995) of young men involved in conservation activism, "where gender hierarchy has lost all legitimacy" (p. 90). I could easily imagine Dick, for instance, saying this quote from one of Connell's cases: "That experience of being alone, wandering round and doing things and appreciating things and enjoying a beautiful place can really give me a wonderfully clear, pure feeling" (p. 128). 
His solutions for the problems related to the wildlife he loves are non-violent:

For himself, he loves the animal life (bear, coyotes, cougars, bobcats, possums, raccoons). The bears have caused him problems, eating his apples (he has an orchard) and honey (he used to keep bees). The solution he's concluded must be a fence, as he doesn't go for hunting. He feels the combination of sea and forest is great for wildlife. A cougar, a few years ago, attacked [his relative's domestic animals]. The cougar had to be shot and she gave up on raising them. He also said coyotes are a problem but didn't elaborate.

Dick's forest-based activities are relevant as Local harp strings for masculinity: outdoors, requiring and maintaining physical strength (e.g., cutting firewood, running), recognizing the value of logging. His company does construction, a conventionally masculine occupation, he lives in the forest (again coded 'masculine') and he maintains and uses heavy equipment, another interest that serves as evidence of masculinity in this region. His activities and skills surely grant him respect from Locals, but his own value system, as evidenced in this discussion, stresses conservation and protection. He'd like to see the nearby Trident Navy base turned into a nature preserve (in rejection of another stereotypical manly institution).

The last example is Harry, a retired man in his 80 s who grew up in the community and has lived there all his life, a valued member of the Local community (notes, 23 May 2017). ${ }^{31}$ Their house, on the edge of Bushler Bay proper, is small but neat, with a garden full of flowers. Harry has worked as a logger, a USFS employee, in the brush-picking industry and for the US Postal Service. His personal commitment has been to place over occupation. And his comments reflect the usual Local masculine distaste for 'paperwork':

In the USFS, he found that the higher up he went, the more paperwork. He particularly remembered with distaste the reports he had to file about environmental assessments. He'd write them, and someone higher up might or might not like them. He wound up spending time on paperwork he didn't like. He had a chance to be moved [by the USFS] to California, but his kids were in high school and really didn't want to move, so he didn't go. You had to work in at least two forests at that time.

His children's preference for staying in Bushler Bay (they remain nearby) suggests that fatherhood was important to him. Although he is now unable to walk or talk very well, his love of the outdoors is clear. Indeed, his sense of loss, both from his own disability and from the broader changes that have occurred in the area was palpable, though he expressed none of the bitterness I had anticipated (and heard from some). He listed some of the changes, ones with implications for the Local view of masculinity (see also Colfer 2018):

- $\quad$ Logging was key in the 1970s. In the pebble distribution tool, Harry gave 4 beans out of 100 (all for men) for logging. 
- Brush picking was also a going concern for local folks then. Harry now gives it four beans for women and eight for men. This business has been taken over, he says, by Mexicans, Vietnamese and people from Honduras. ${ }^{32} \mathrm{He}$ understands they have a hard life, expressed sympathy but also aggravation and disappointment.

- $\quad$ Firewood used to be a bigger deal. More people used wood for heat and sometimes cooking in the past. Firewood permits were given out by the USFS after a logging job or a blowdown. There are almost no logging jobs locally from the USFS these days.

- Shellfish used to be readily available to anyone, but now the human population has increased, and people are unwilling to share with others - the land is privately owned (as before), but the norm to let people gather no longer applies.

- Mushrooms are also collected on a broader scale by the Vietnamese (though some do remain for local folks). ${ }^{33}$

- The regulations for fishing are one a day of at least a foot in length; the rule used to be 20 a day, as small as 6" in length.

Although both men and women engaged in all these activities, to varying degrees, they were central to men's outdoors harp string in a way that wasn't relevant for womanhood. In the past, these activities had been important for provisioning and some subsistence, as well.

Harry's love of nature also came out loud and clear when I asked about the places he liked to go. Because of his infirmity we discussed where he'd gone in the past. Looking at a map,

he picked the Mt. Townsend area and then Buckhorn Wilderness as places he used to fish and hike. He loved those areas and also went there when he worked for the USFS, plus to Gray Wolf River (before these areas were termed Wilderness Areas-now you can only fish and hike). Then he remembered he liked rivers, so he pointed out the Big BB. Then he remembered the Dosewallips which he also likes - both for fishing. [His wife] is from up the Dosewallips, and he remembered that he used to go there to see her before they were married. Obviously fond memories. He said the Dosewallips is a really beautiful river. There was a landslide there that took out 7-8 miles of the road to the [Olympic National] Park. They've been trying to get the USFS to fix the road but so far no luck. I felt I was making him think sad thoughts (sad that he couldn't do these things anymore), so I changed the subject.

He also expressed the same love of wildlife that Dick had shared.

While we were talking Harry expressed his distaste for people hunting bears. He was ok with [their hunting] deer and elk and used to do that himself for food; but he liked bears, saw them a lot when he was brush 
picking and they never bothered him. He said, "I got to a point where I didn't want to kill things anymore". What a nice, gentle man he is!

Given Harry's age, hunting, fishing and gathering had a serious provisioning function earlier in his life. And he has managed to remain employed for the better part of his life, including some work with the post office even now, suggesting a serious commitment to the breadwinner harp string.

But his wife's active involvement in paid labour now suggests an open attitudedifferent from Local attitudes in the $1970 \mathrm{~s}^{34}$ — toward a woman's employment, as well as probable financial need. Although I did not see them together on this visit, our interchanges about when to meet reflect an active life of community involvement as well as what must be a significant caretaking role on the part of his wife. His ways of interacting with me and talking about her suggest he does not see his role as 'controller' of his wife. He fits in with her busier schedule. ${ }^{35}$

Other interviews and observations portrayed additional harp strings. Men discussed their children. One widely admired Local described his regret:

He has some things he regrets, like not spending more time helping his wife with the kids. He's proud of the two youngest, including [name], whom I remember from high school.

(notes, 2 June 2017)

The most consistent concern in the community, expressed by all ages and genders, is the lack of employment opportunities for their adult children and those of their neighbours. The men are as likely to express this concern as the women. One girl talked of always going hunting with her father; the pebble distribution results also reflect women's involvement in hunting. Another man reported the bonding function of taking his adult son camping in the Olympic Mountains after a traumatic experience.

The caring/loving harp string pops up again and again. Tom expressed his caring most consistently in connection with his role as protector. Dick talked of his love for wildlife; his care about the forest was obvious. Harry's care about rivers and wild areas was evident, and all three obviously loved/cared about their wives. Many folks mentioned their love for the forest and the environment, making efforts to care for it; some loved their jobs.

Interestingly, especially given its importance in the Bushler Bay of the 1970s, no mention was made of sexuality in all these interviews and informal conversationseither by men or women. I would be surprised if sexuality does not continue to be important to men (e.g., the Pecker Pole beer brand); but there have been news reports about the reduction in sexual activity among America's youth as well as evidence that sex declines in importance as people age- a topic for further research.

A couple of older men mentioned local political action, which in the 1970s had been largely in women's hands, via club activity (Colfer 1977). Now, men's 
discussions centred on their dissatisfaction with the lack of responsiveness of county government, rather than the very local school levies, provision of streetlights and sports-related issues of old in Bushler Bay proper. There was also an assumption in people's visions of the future that the formal government (USFS, US Park Service, DNR) would and should be responsible for maintaining the forest, for which all expressed a desire. There were complaints about the specific policies and actions of the USFS, for instance, insufficient cutting, insufficient re-planting, too little money, too few workers and too few local jobs. But I heard no aspersions against the masculinity of government workers (many of whom are women now).

\section{Bushler Bay summary}

Although there have been very significant changes in Bushler Bay, many of the chords of masculinity remain. Men in their productive years are still concerned to fulfill a provider role; many, including both Locals and amenity migrants, link outdoor work, physical strength, courage ${ }^{36}$ and independence in an important chord. Fatherhood and caring remain important for many as well.

But some significant changes have occurred. The most obvious is the change from Local men's sense that they should control their households to a more companionate view of marriage-more closely approaching the previous Public Employee tendency. Yet all the marriages I observed and discussed appeared to value gender equality - even in the one case where the husband claimed control (separate but equal) - far more than was the case in the 1970s. Several women also insisted that "women can do anything a man can do". The retired Local owner of a logging firm bragged to me that he had consistently employed a woman as a log truck driver, along with other attitudes indicative of what would have earlier been unusual respect for women.

He remembers his own grade school teacher [a woman] with admiration and respect; he admires the very bright and successful wife of his brother (who didn't have a job, though perhaps he worked on their farm??); he treated me with complete respect despite our differences of [political] opinion; he had hired a woman (who also had an apparently affectionate nickname) as a log truck driver for years.

(notes, 2 June 2017)

Although no mention was made of the team sports that were so central to masculinity in the 1970s, this may have been because of timing (the school year was ending) and/or sports' intimate links to the high school-the school being a context to which I had minimal access. ${ }^{37}$ The recent, more inclusive attitudes reported by Anderson (2009) for college sportsmen in the US and UK may have 
reached or evolved in Bushler Bay as well. Sexuality, hierarchy and the arts were similarly not explicitly mentioned (which, given the brevity of this research, does not mean they weren't important).

A political harp string, which globally can be an important part of masculinity (discussed later) has become clearer among some Bushler Bay men. In the past, women took care of local politics and Public Employee men participated in their work lives, in governmental bureaucracies. Now, far fewer are employed, and many more who are, are women. Some of these elderly men now engage with politics, locally and reaching at least to the county level, suggesting a greater acceptance of hierarchy, as government bureaucracies are by their nature hierarchical. The fact that tourism, now so important in Bushler Bay, is more similar to bureaucratic work in its lack of a clear product (logs to the landing, loads to the mill) and 'time put in' rather than measurable output may contribute to a broader comfort with the hierarchy harp string.

\section{Observations from Long Segar and Long Anai in 2019}

In March 2019, I returned, first to Long Anai, ${ }^{38}$ and then to Long Segar, East Kalimantan for two weeks (see Figure 4.1). During that time, I again conducted 'ethnography light' as well as a one-page survey administered to opportunity samples of 134 adults in Long Anai (total population: 435) and 143 in Long Segar (total population: 837). The survey in both communities repeated several questions that had been asked in a 1980 survey (Colfer 1985a, b), dealing with gender dynamics. ${ }^{39} \mathrm{I}$ had been communicating on Facebook with people in both communities, including scanning and posting old photos for them; they knew I was coming.

I was accompanied on the visit to Long Anai by my 95-year-old mother, my son (co-author Pierce) - both of whom had visited before-and his JavaneseAmerican wife. We were welcomed, as usual, into the home of Pierce's father's previous wife. Although I had wronged her in 1980, she had long since forgiven me, partly because I had helped her and her family from time to time but also because of the norm that once one paid one's fine (as I had), the issue was finished (see Chapter 4). We were touched by the kindness and welcome these folks extended, particularly to my very fragile and inconvenient mother. They had insisted we bring her, even though her presence required them to buy a toilet, build a bed and borrow an easy chair, as well as helping her on and off multiple motorcycles.

I proceeded, after a week, to Long Segar, accompanied on the journey by Pierce's father (whose name has changed $;{ }^{40}$ I'll call him Penjau) and two other elderly Kenyah men, one of whom I'd also known well before. Transport was provided free by one of the oil palm companies trying to gain more land in Long Segar. These Kenyah friends left me at the edge of the Telen River and returned to their home communities (feeling no longer welcome in Long Segar, because of conflicts over land). I was taken in by one of the sons of the family with whom 
I'd lived in 1979-1980, and welcomed (in both communities, with more enthusiasm than in Bushler Bay).

As in Bushler Bay, I confronted very different worlds from what I had seen in earlier visits. The landscapes by which these two communities are now surrounded has changed utterly. Whereas previously there was a complex mosaic of primary and secondary forest, with agricultural fields interspersed, now the predominant feature of the landscapes is large-scale oil palm plantations. ${ }^{41}$ In Long Segar, reportedly for three kilometres either side of the Telen River, land remains for the people to manage, ${ }^{42}$ though the companies continue to seek access to more land. The same process is underway in Long Anai, with the addition that now mining companies have joined the fray and are also negotiating with local people to gain access. ${ }^{43}$ Another new complication in Long Anai is the recent decision to move the Indonesian capital to their district.

In the following discussion, I return to the harp strings described in Chapter 4 , and insofar as possible, update that discussion.

\section{Expedition-making and masculinity}

As noted earlier, a key harp string in Kenyah masculinity has been expeditionmaking. In the 1970s and before, men made their way to Malaysia and beyond; in more recent years, they have made extended trips throughout East Kalimantan. But Kenyah men are not now making such trips. The opportunities for landclearing jobs, one of their longstanding skills, have evaporated as the forest has been cleared.

Additionally, because of external pressures on the land surrounding the two villages and resulting uncertainty about tenure, men are reluctant to leave. Many fear that in their absence, their family's land is more likely to be taken over. Although the Kenyah have traditionally considered a family's cleared land to belong equally to its men and women, outsiders (from the government, industry, even NGOs) tend to consider land to belong to men-insofar as ownership rights are granted to the Kenyah at all. Such rights are negotiated on a case-by-case basis. ${ }^{44}$

\section{Leadership as a harp string}

Although the issues being discussed differ somewhat, given the prominence of oil palm these days, the nature of leadership appears very similar to its traditional pattern in Long Segar. With the current kepala adat (customary leader) the son of Pelibut (the previous commoner headman), there remains a sub rosa concern about the Paren-Panyen (aristocrat-commoner) distinction, ${ }^{45}$ with Panyen individuals arguing, for instance, that demonstrated ability to lead rather than one's ancestry should categorize one as Paren.

There also remains significant competition for recognition as leaders, among men of similar age. Three elderly men, whose competition was obvious in 1979, continue to compete for decision-making authority, power and 
resulting accolades in 2019. Two of these men are co-resident in Long Segar; the third, Penjau, lives elsewhere but has come together with leaders from Long Anai and Sungai Bawang (both daughter villages of Long Segar) in order to resolve a land issue that also pertains to the oil palm company that provided our transport. ${ }^{46}$

All these men had cleared land in Long Segar at one point, but the latter nonresidents, had moved away decades ago. The question is, what should become of the land cleared by those no longer residing in the community? This was a bone of contention also in Long Ampung (the remote community from which the Long Segar population originated) in earlier times. Should non-residents retain rights to the land they cleared or should it return to the community's estate, available for use by those remaining?

This question becomes more complicated when oil palm companies' interest in gaining access to that land emerges. There is considerable scope for payoffs from the company to leaders and for manipulating existing community factionalism, thereby reducing local negotiating power. Formal Kenyah leaders are confronted with many temptations, a serious dilemma for some. Although such temptations are not new, as the amount of land available goes down, the adverse implications of leaders' possible collusion with companies goes up. Such troubles have beset both communities, with resulting community suspicion of men who lead (again, nothing new).

Considerable communication has long existed among leaders of different Kenyah villages, with reciprocal knowledge about each other, including crossvisits among them. Such communication is much easier now, with roads, cars, motorcycles, cell phones and Facebook-all of which are available to some residents of both communities. The fact that these new devices, as well as educational achievements, are more available to the young may at some stage have implications for the Kenyah preference for leadership by the elderly. However, elderly men appear to remain in control of major community decision-making at this stage (with easy opportunity for any who choose-man, woman, youth - to make their views known to these men).

Our 2019 survey asked each respondent whether he or she attended community meetings and whether they spoke up in them. Although we see slightly more gender differentiation in Long Segar (see Figure 7.1), in neither community was the difference statistically significant. But there are marked differences between the two villages, with $90 \%$ of women and $93 \%$ of men claiming to attend village meetings in Long Anai, and only $58 \%$ of women ${ }^{47}$ and $76 \%$ of men in Long Segar reporting attending.

Figure 7.2 shows comparable data on the likelihood of women and men speaking up. Those in Long Segar are somewhat less likely to speak up in meetings than in Long Anai, perhaps reflecting the younger, more educated and more urbane population in the latter community. But again the gender difference is not significant in either community. 


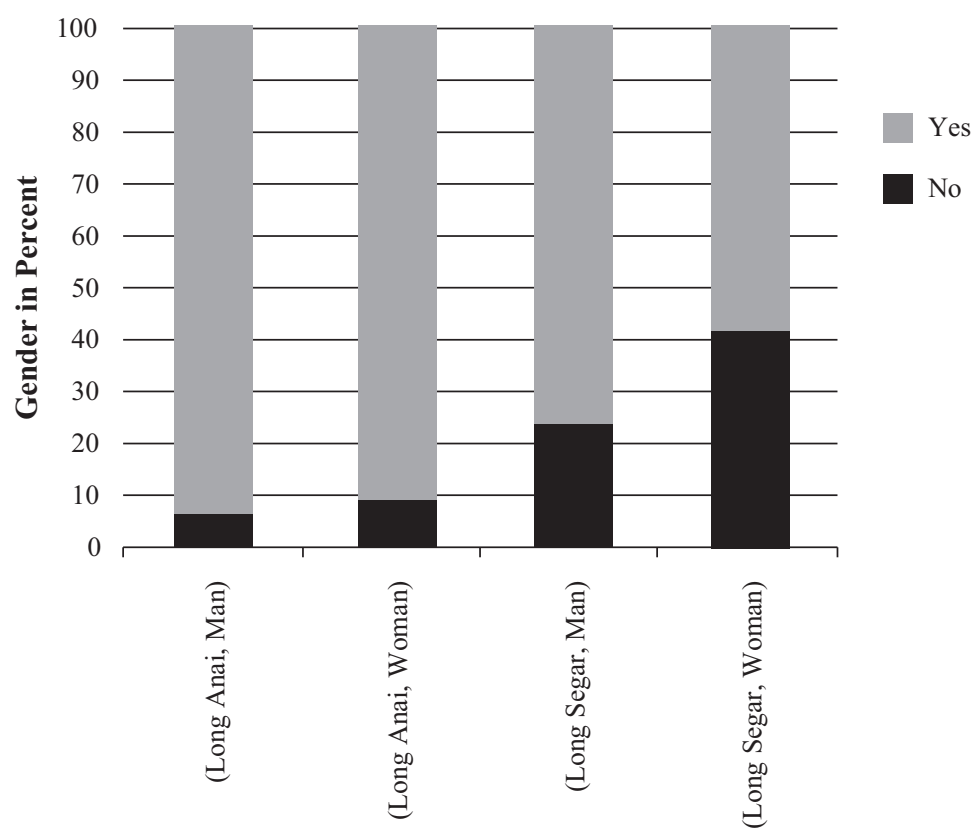

Sites by Gender

FIGURE 7.1 Self-reported attendance at community meetings, Long Anai and Long Segar, March 2019.

\section{Provisioning as a harp string}

As noted earlier, provisioning in general has been shared between Kenyah men and women, with men providing money and goods and women providing rice and other agricultural products. One would expect the fact that the percentage of people making rice fields has plummeted in Long Anai (95\% of women and 93\% of men reported not having made a 2018 field) would have a significant effect on the gendered distribution of labour. This is very different from Long Segar, where only $21 \%$ of women and $20 \%$ of men reported not making one. Despite the huge community difference in swiddening, the responses of men and women are not significantly different one from the other in either case. Women's upsurge in paid employment in the oil palm industry and involvement along with men in other agricultural endeavours in Long Anai appears to be substituting to some extent for their traditional rice production.

There is considerable evidence available on Facebook that the Kenyah continue to harvest some products from nature (particularly fish and some forest plants). The fact that they now buy much of their food (a big change from the past, when bought food in three surveys, 1979-1980, 1991 and 2001, ranged 


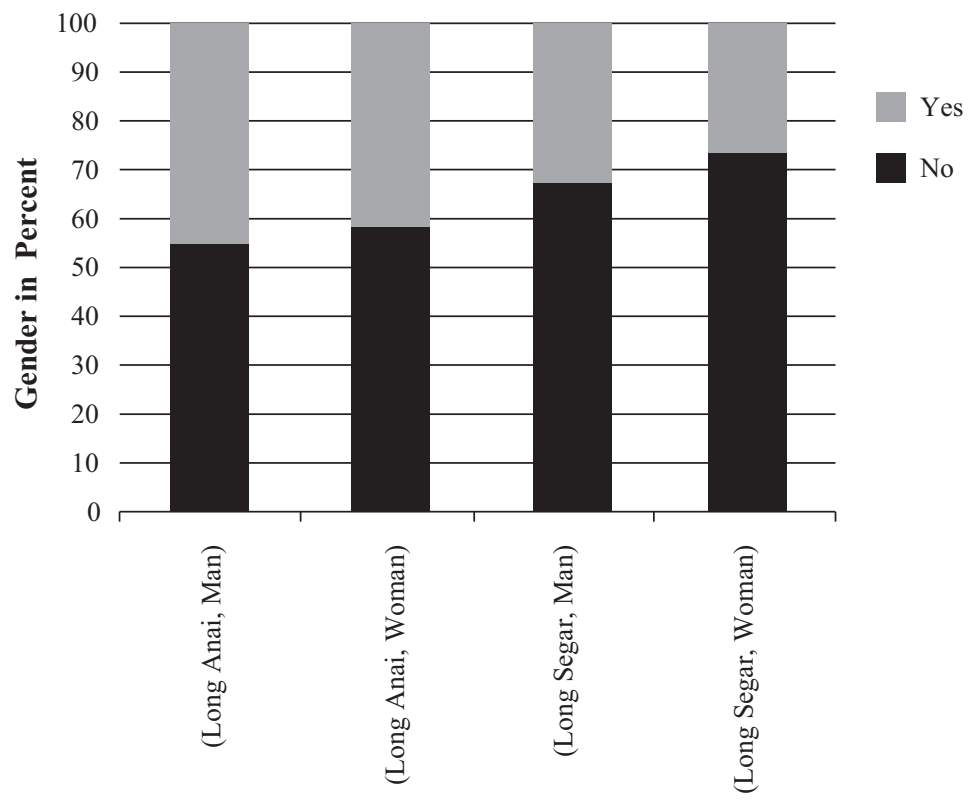

Sites by Gender

FIGURE 7.2 Self-reported willingness to speak up at community meetings, Long Anai and Long Segar, March 2019.

from $5-10 \%$ of their diet; Colfer and Soedjito 2003) derives partly from a simple lack of forest from which to harvest their traditional products. The reduction in hunting represents a reduction in men's provisioning roles.

Additionally, as land pressure has reduced the amount of available land, women have reduced the sizes of their fields and no longer sell surplus rice, which had been a ready source of cash and trade for them. Although men have typically had easier access to larger sums, through their expeditions and resulting wage labour, this is much less available now. Men complain that there are no land-clearing jobs. ${ }^{48}$ That, combined with their reluctance to leave home due to concerns about land insecurity, means they are shifting their focus to smallholder oil palm and other commodities as potential sources of income. Families in both places have been developing a two-pronged approach: In Long Segar, the women continue to focus on rice for subsistence (sometimes supplemented by wage labour at the nearby oil palm plantations) and the men focus on kebun (gardens/orchards) — with each also contributing labour to the other's endeavours.

In Long Anai, both men and women in many families work for the oil palm industry, ${ }^{49}$ also maintaining kebun for cash crops. Long Anai, only a three-hour drive from Samarinda, has been more involved in the sale of produce than Long Segar from its inception. Another motivation to develop kebun is the governmental perception that crops planted in rows are clearer evidence of use, necessary for 
any kind of external recognition (so far, still vague or non-existent) of rights to the land. ${ }^{50}$ Finally, the development of kebun involves some tasks that are said to benefit from men's typically greater physical strength.

Insofar as Kenyah men's masculinity is closely linked to provisioning, the greater educational accomplishments of young Kenyah women may be seen as a potential threat. A number of Kenyah women, probably at least as many as Kenyah men, have office jobs with the government, NGOs or industry. A minority of husbands follow their wives. One of our relatives stayed home to look after their children. Although he would have preferred to work for wages, his main concern seemed not to be an attack on his masculinity, but rather his wish to demonstrate that he was a hard worker, a key pan-Kenyah value.

Our survey asked about how decisions relating to household income were made: Did you help decide how to spend household money last year? Alone? If not alone, with whom? ('Iko' mepoh pekimet kompin pakai uang kem uman ca re? Tengen? Bek mpi tengen, ngan 'ee?'). ${ }^{51}$ The responses are shown in Figure 7.3, with no significant gender differentiation in either community, and not a great deal of variation from one community to the other. In both communities the most common response was that husbands and wives decided together.

Sharing was a strong value among Kenyah men (and women) in 1979-1980, and it continued strong in 2019. Walking along the street in Long Anai, I was

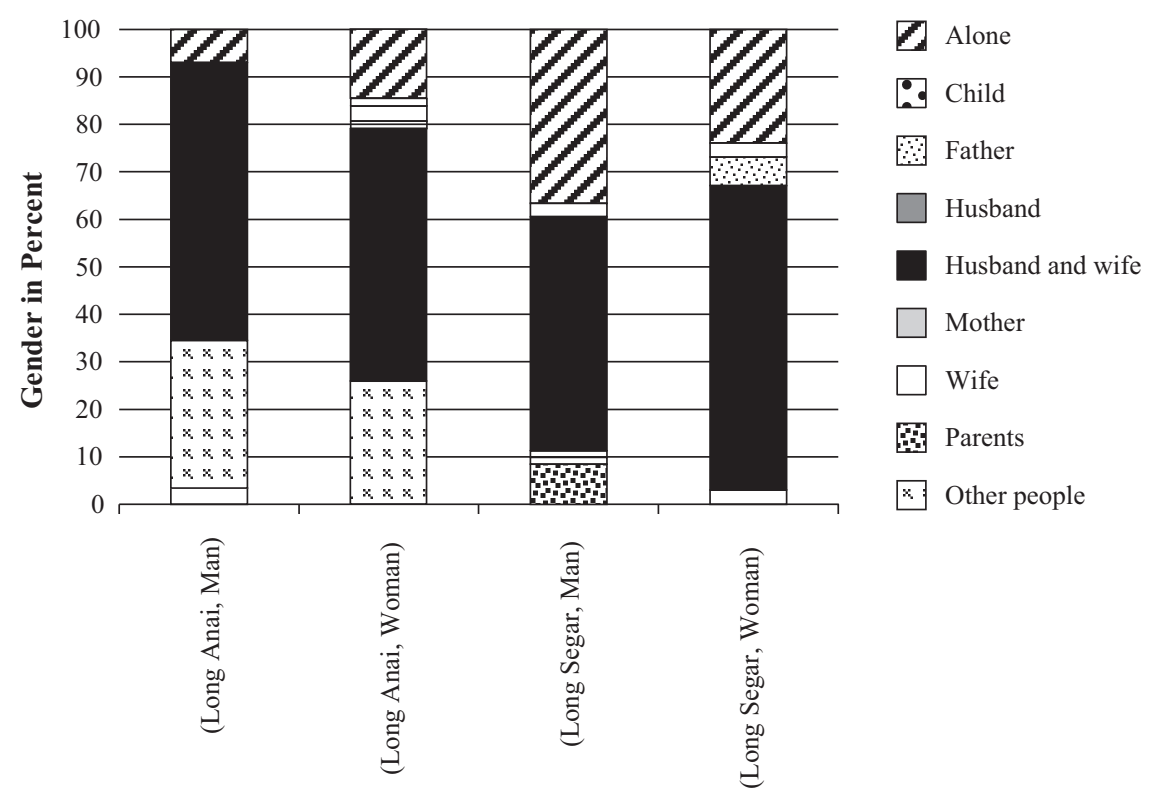

Sites by Gender

FIGURE 7.3 People with whom respondents made decisions about household money in Long Anai and Long Segar, March 2019. 
offered some of any produce people might have in their backpacks or on their motorcycles. In Long Segar, the family I stayed with and the community at large organized get-togethers, where food was brought and prepared communally and shared among any who chose to come (visitors could also bring home banana leaf packets of food for housemates). On Facebook, people show what foods they have gathered or are eating; others express their desire to share it, a desire often recognized with invitations to come have some. Although I cannot confirm with current evidence, I suspect that gathered and home-grown products are more readily shared than those which are bought. That would certainly have been the case in the past. Some efforts are made to hide what people would rather not share, but any visible abundance is expected to be and usually is shared.

\section{Protection, strength, courage and violence ${ }^{52}$}

As noted in Chapter 4, the forest was considered a dangerous place, a place for men more than women. The man who was a midwife (see Chapter 4) had lost one leg to a wild pig; Dinis, one of our interviewers and my stepson, had a huge scar where a wild pig had attacked him and taken away part of his arm. Such encounters were not rare. The fact that the forest is basically gone means that men have lost an opportunity to display their strength and courage regularly.

In earlier visits, the Kenyah, both men and women, expressed concerns about ayau. Ayau is the term they used for headhunters in the past, but by 1980, they were using the same term for any violent non-Kenyah. The fact that there are now many more individuals from other ethnic groups living and working nearby has meant an increase, at least in Kenyah perceptions, of danger.

One proxy for people's feelings of danger is their willingness to sleep alone in their fields. Figure 7.4 shows women's and men's responses to this question in the two communities. Neither the gender differentiation nor the differentiation from one community to the other is significant. But this distribution of responses is markedly different from the 1980 results from Long Ampung and Long Segar, where $\sim 84 \%$ of women in both communities reported staying alone at their fields (Colfer 1985a, p. 202). ${ }^{53}$ Ayau were a source of fear at that time as well.

The Kenyah tend to have strong negative stereotypes of Bugis [an ethnic group originally from South Sulawesi], often noting their propensity for violence and aggressive use of knives. Most other ethnic groups (from Sulawesi, Nusa Tenggara Timur, Java) have more hierarchical views of male-female relations than do the Kenyah, with stronger narratives of female inferiority-thus suggesting greater need for male protection than had been the case in earlier years. As discussed in Chapter 5, interaction between ethnic groups can strengthen gender stereotyping as ethnic groups strive to emphasize the norms and roles of their particular group vis-à-vis those of others.

But Kenyah stereotypes of others are well matched by negative and fearful stereotypes about themselves. Pierce recounts here some stereotypes he's encountered in Boxes 7.2 and 7.3. 


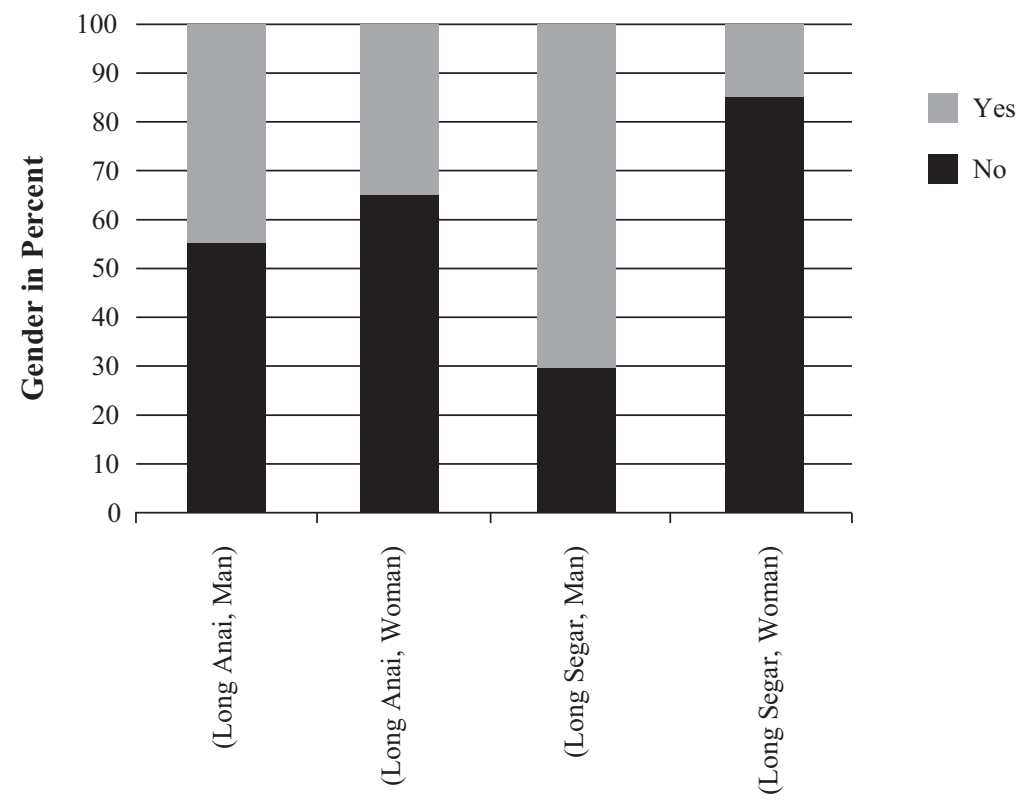

Sites by Gender

FIGURE 7.4 Willingness to spend the night at one's field without one's spouse, Long Anai and Long Segar, by gender, March 2019.

\section{BOX 7.2 EXAMPLES OF UNFLATTERING AND FEARFUL STEREOTYPES ABOUT DAYAKS FROM OTHER ETHNIC GROUPS}

Minangkabau: "Where is your spear and why are you wearing clothes?" a woman from West Sumatra said jokingly to Pierce. The same woman, Pierce's friend, told him, "You are protected; I see spirits that protect you, that are always with you".

Ambonese: "Ah Dayak, your magic is almost as strong as ours. In my village, our Dukun [magic healer] can fly on a leaf; can they do that in your village?" said an Ambonese man (also reputedly a killer-for-hire in Bogor, Indonesia, 1998).

Javanese: “Don't go to Kalimantan, because you will come out with a penis on your forehead if you ever try and leave a Dayak woman. Most people who go there never leave". Also "Dayaks have powerful love magic".

Australian-Indonesian: "I don't believe in magic, but l've seen a lot of friends of mine be mind-controlled (santet) to fall in love with Dayak women. A good friend of mine loved his wife, was the perfect family man, had 
pictures of all his kids in his office and one day he just left ... left his family, his job and started living with this woman. We couldn't believe it, but I saw it happen and there were many other stories like that" (from friend who had long worked in mining in Kalimantan). ${ }^{54}$

Assorted Indonesian ethnicities: "Dayaks can send a sword that flies through the air and it will kill you if you are of Madurese blood". This sentiment was heard repeatedly after the 1996-1997 inter-ethnic violence in West Kalimantan between Dayaks and in-migrants (see Peluso 2008 for a good summary of this violence). "Dayaks can smell a Madurese. They'll come on a bus and pick out the Madurese by their smell".

Additionally, my well-educated and intelligent Balinese hostess in 1979 expressed fear when told that I was going to East Kalimantan. She believed that Dayak women were very white and thus particularly beautiful, and that Dayaks had tails.

Here, to better capture Kenyah men's perceptions of manhood, I have enlisted further aid from Pierce, my son, who has spent almost half his life in Indonesia. Borrowing the eyes of a man in his 30s seemed a useful complement to our survey results. Although much of Pierce's life has been spent in urban Indonesia (Jakarta, Bogor and more recently, Denpasar, Bali), he also spent three years in rural West Sumatra (from ages three to five), another year in remote West Kalimantan (age 11), another year as a construction manager on the rural island of Matak in Riau Province (2011-1012) and has periodically made family visits to rural East Kalimantan.

He has had moments of some fame in Indonesia (due to a brief advertising career, then brief involvement in televised cage fighting and other martial arts). Part of his adult life, he focused on his artistic talents, and then shifted to entrepreneurial activity in construction in the US, then recently to several businesses in Bali. He has recently again plucked his artistic harp string.

As a 'people person', whom others usually enjoy, I enlisted his help in recounting what he'd learned about current Kenyah masculinities as shown by his halfbrothers and others in Long Anai. Pierce's size (6'2”), strength and fighting skills (proven in a video of his nationally televised cage fight from 2003) were obviously admired in this community, and he was entertained nightly with stories of men's lives in Long Anai. We include several such tales here, reflective of masculine actions and perspectives.

\section{BOX 7.3 THE FEARS OF OTHERS ENCOUNTERING THE KENYAH}

In Long Anai, Taman, a Tunjung Dayak married to Pierce's Kenyah half-sister, told a story of a Javanese palm oil plantation worker who avoided others, never speaking to anyone. He ate alone and always looked frightened. After 
a couple of weeks, Taman went to him and introduced himself, to break the ice. He felt sorry for the guy, without friends. The man nervously gave him his name and immediately and fearfully said the first thing on his mind: "In my village, they say Dayaks eat people, but I haven't seen you eat anyone". Taman described the man's reply, with incredulity and laughter.

"You thought that we eat people and you still came here?!" Smiling, Taman said, "I told him that we did not eat people and that that was generations ago and rarely happened, that none of the Dayaks in my lifetime have eaten people". [He judiciously excluded the 1997 Dayak-Madurese conflict in West Kalimantan.] Taman patiently explained his Tunjung and Kenyah life philosophy and culture. The man's fears eased over time, allowing him eventually to feel comfortable surrounded by Dayaks.

Several stories were recounted about groups of Kenyah men banding together to confront outsiders - an event the frequency of which has only increased in recent years. Physical strength shows up as an admired harp string. In one case, the men of Long Anai invited a group they referred to as the 'Dayak mafia' (a group of hard drinking, womanizing, drug-using urban Dayaks ${ }^{55}$ to help them in a conflict with an oil palm company. The Dayak mafia was reputed to be 'skilled at the table' (able to bluff, pound the table, threaten). However, in this case, that approach failed, and the group decided to resort to violence. ${ }^{56} \mathrm{With}$ spears, bush knives and a few guns in hand, they began a two-kilometre hike to company headquarters. But the Dayak mafia, composed of fat, slow 'city folk', was reported not to have the stamina even for the walk, giving up halfway there. The Kenyah recounted this story with great disdain for the physical state of these visitors. One said, "How are they going to fight if they can't even get to the battlefield?!”

In another case, which documents the kinds of trickery to which the people have been subjected, violence proved a harp string worth plucking (though apparently not successfully). A huge Korean mining company was not hiring local people as promised in their original agreement, which granted the company access to land. The people came together en masse to complain and demonstrate. The company backed off and agreed to improve their practices. The head of the district agreed to put in a two-week apprentice programme to train local people. $\mathrm{He}$ is reputed to have received $\$ 700,000$ from the company to implement the programme. However, nothing happened, and the mine kept operating. Such actions by companies and government officials have led to bad blood with the communities and retribution in the form of reciprocal community trickery, as also reported elsewhere. Legal means are not helpful: judges can be bought off by the wealthier companies. People feel their only recourse is violence, usually by men (notes, 19 March 2019), though women are sometimes included.

Stories of hunting praised men's skills and derring-do (see Box 7.4). Interestingly, Pierce, a strong and demonstrably courageous man himself, was told more 
stories of this ilk than I, in this short visit. This story portrays other masculine harp strings reminiscent of masculinities among scientists: 'being good at speaking' (evident in the telling of these tales) and having knowledge and analytical skills.

\section{BOX 7.4 BILUNG, AN EXCELLENT HUNTER FROM LONG ANAI, MARCH 2019}

Bilung has a reputation as a good hunter. He shows me a picture and the skin of a six-metre python he killed. He was able to sneak up on the python, preoccupied eating a baby pig, and kill it by stabbing its head into the ground with a spear. The baby pig tried to run away, but Bilung was able to catch and kill it also, with a bush knife.

On another occasion, he told of killing a honey bear as night was falling. Its mate came and chased him; he tried to fight it with a stick but realized that fighting at night was going to be even more dangerous. He couldn't run up a tree because the honey bear would follow and trap him there, so he ran away ... but he really wanted to do battle with the bear. He said to himself, "I will retreat now, but you will see tomorrow. I will come for you and we will fight". He returned the next day, finding the bear in the same clearing where he had killed its mate. The bear, in fear, ran away.

As he recounted this tale, he explained the advantages of his technique over that of one of his agemates. He broke down the elements of strategy and skill necessary to hunt well, the art of reading tracks and body and weapon positioning. He called himself a tactician. His friend, on the other hand, has great courage, he said, but is not sufficiently tactical. "You watch an animal's movements and patterns and study them. Then you can hunt well". He then told a story of his friend's incorrect positioning, which nearly got him killed. "[His friend] is reckless; this is very dangerous. You have to be tactical and always secure a superior position before you attack".

Once, for instance, Bilung followed two adult pigs with two little ones deep into the forest. He saw where they were headed and got on a log below which he predicted they would pass. Having only a machete, he threw it at the big male, hoping to stab it cleanly, but the machete bounced off and the adult pig ran. Bilung jumped onto the piglets, catching one, wrapping it with one arm and his legs, and grabbing the other with his other arm. Unable to kill them both because his machete was out of reach and with no hand free, he let one piglet go, and managed to kill the other. He was in great danger, as an adult pig can kill a grown man easily with its tusks or by its bite, let alone a male and female pig protecting their young.

Bilung was also one of the few willing to hunt crocodiles with spear and gun. He would track them by their eyes which protrude from the river and shine in the night. He used a barbed spear, striking through the mouth and then shooting them in the head. 
One of Bilung's cousins, Dinis, was also an excellent hunter. He would sometimes take his makeshift rifle with only three bullets into the forest and stay for two to three days alone, hunting wild pigs. Since bullets are expensive, and no one could afford modern firearms, he used a gun that required him to jam a bullet into the barrel with a rock each time he reloaded. I was with him on such a hunt in 1999 and feared the whole while that the bullet would explode in his face, showering us with shrapnel. Thankfully this did not happen. (Pierce's notes, 19 March 2019) ${ }^{57}$

These two men (both Paren) have invested strongly in the strength, skills and courage harp strings; the teller has plucked the articulateness harp string. Not all Kenyah men choose strength, courage or articulateness.

Another story from Pierce, however, reveals womanly courage, a lack of male protectiveness and a willingness by men to acknowledge fear.

\section{BOX 7.5 A KENYAH WOMAN'S COURAGE}

In 2009, I'd gone fishing with my brother-in-law (the above-mentioned Tunjung Dayak) and his Tunjung family also visiting Long Anai. These Tunjung had little experience with fishing but were famous instead for climbing the tall, majestic honey trees (Koompassia excelsa), the latter widely recognized as requiring great courage. A group of Kenyah men, excellent fishers, agreed to try to teach them all how to catch fish with their hands. On this day, the Kenyah men caught many fish, whereas the Tunjung were coming up empty-handed.

Halfway through the day, I heard a high-pitched scream and turning around, saw a thin stripling of a tree-from which dangled my brother-inlaw, swaying about a metre above the water, legs splayed and shouting, "Snake!!! Snake!!!" The other Tunjung men had scattered to the river bank like buckshot. Half laughing, half fearful, I ran to shore, picked up a machete and a stick to pin the snake's head against the tree. I yelled out, "Do you see it?". He answered, abject terror clear on his face, "I see its head. It's right there. I see its head!" I waded back into the water as all the Tunjung stood huddled together on the shore, unwilling to re-enter the water. As I got closer, I saw the snake's head at the base of the tree. Just as I was about to pin it with the stick, the head disappeared. I waited a moment and then, like the Tunjung, raced back to shore, also not wanting to get bitten by a snake!

Just then, two Kenyah women passed by with rattan backpacks three quarters full of fish. . . . about 20 times the amount that we had caught, our sole saviors being Bilung and his brother. One of the women yelled out, "What's the problem?" 
"There's a snake under that tree", I said, "but it disappeared".

"Oh, just a snake". She turned around, pulled her machete from its casing, cut a forked branch, hacked off the two ends and waded through the water to the tree. We all watched, nervously. In a matter of five seconds she'd pinned the snake's head, cut it off, grabbed the body and flung it into the forest. She walked off laughing at our ineptitude and cowardice, having out-fished all nine of us. When I reminded her of this outing in March 2019, she just laughed dismissively.

On another occasion, another woman, known for her courage, held a python by its throat and allowed it to wrap itself around her arm, wondering how hard it could squeeze. When her arm began to turn blue, she smashed in its teeth, and unwrapped it from its tail (reportedly the 'proper way' to remove a python). Her husband had fled. (Pierce's notes, 19 March 2019)

\section{Sexuality}

Getting a proper sense of people's attitudes toward masculinity and sexuality may be more sensitive and thus iffier on a short visit than most topics. Kenyah attitudes appear to remain quite open about sexuality, however, and important to men. In one of the homes where I stayed, one adult son was openly sleeping with his fiancée, without any evidence of disapproval. However, as would have happened in earlier times, young people were discouraged from making love before marriage. At an engagement party we attended in Long Anai, four elderly men gave speeches of advice to the young couple, and all reminded them that they should not be making love yet (along with pleas for understanding of their cultural difference [one was Kenyah and one Batak], and for love and problem solving between them). Interestingly, in contrast to weddings attended in Long Segar in 1979-1980, no mention was made of the marital sex roles American missionaries had then deemed appropriate for men and women.

There continued to be community approval of marriage as the most appropriate life path for both men and women. In Long Segar, some concern was expressed by elders that a fair number of young people were not marrying. I encountered two unmarried men and two unmarried women in their 20 s and 30 s, all reluctant to marry, though I don't know why.

The greater amounts of interaction in both areas with individuals from other ethnic groups has linked sexuality and violence in a way that did not appear to be the case in the past. In one example in Long Segar, a man from another ethnic group and a Kenyah women wanted to marry; he brought her presents as a sign of his commitment. She then changed her mind but did not give back the presents. The man did not find this acceptable and kept harassing her about the issue. A group of Kenyah men, unhappy with his insistence, went en masse with weapons to find the man and beat him up. ${ }^{58}$ They were stopped by the timely 
arrival of the police in the other community, who were able to negotiate a peaceful solution.

A similar case occurred in Long Anai. A non-Kenyah man became friends with a Kenyah man and his wife, eventually resulting in her disappearance. It was not clear whether the other man had persuaded her to leave her husband or had abducted her. Her husband was not inclined to pursue the matter, but other community members felt that it was important to find out whether she'd gone willingly or not. If she had indeed been abducted, they felt some compulsion to demonstrate more broadly that the Kenyah would not put up with such behaviour. They recognized that one of the few powers they have is other ethnic groups' fear of them.

There were also tales told by older men. One man of 72 (well known in his younger years for sexual peccadilloes) recounted the jealousy of his considerably younger wife. She had gotten so mad one time that she'd bitten a chunk out of his thigh, a story told far and wide (and with amusement). Another Long Anai man in his early 70s had taken his wife to Kenyah court for her jealousy (see Box 7.6).

\section{BOX 7.6 SEXUAL JEALOUSY AMONG THE ELDERLY}

On a long trip, in a car with three elderly, politically active men: One man (in his 60s) had just had a fight with his wife. She was mad at him about an incident from three years earlier: There had been a pretty woman from another village who liked him and sought him out (it wasn't clear whether he responded or not), and his wife got very jealous. At the time, people came together to hear this problem, and they asked both the man and the other woman if they'd been sleeping together. They both denied it. At the time, his wife was fined for being so jealous. Recently in the purported corespondent's household, a new baby had been born, who was the man's 'grandchild' (not necessarily a direct lineal descendant). He went to see the baby, raising his wife's ire again. During the argument, he reported grabbing his genitals and saying to her, "This is what makes you so jealous!". The other two men listening to this story nodded in sympathy. There seemed to be general agreement with this interpretation; all also agreed that getting jealous is a bad thing. One of the other men had commented earlier that he liked to look at pretty women, but his body was weak now and he couldn't do anything about it.

A final example comes from a recently widowed man of around 80 in Long Segar. He had fallen in love with a young woman who was polite but not interested in him romantically. His agemates berated him to me, feeling that he should find a woman closer to his own age. They also disapproved of his continuing to 
pursue the younger woman, when they felt it was clear she didn't want himthough she had never exactly said so. One elder said "Women are polite. They're not going to say, 'I don't like you.' They'll make up excuses”. This elder went on to say, "I'd never pursue a woman who wasn't interested in me. There are plenty of women, and it's easy for a man to find another woman". He clearly thought it was easier for a man to find a wife than for a woman to find a husband (which indeed seems to be true).

The interesting thing about these examples comes partly from a comparison with the situation encountered in Bushler Bay, where sexuality-so important in the 1970 s - did not come up in my interviews at all. ${ }^{59}$

\section{The arts}

Although excelling at the arts is not an avenue open to all men-since most consider artistic ability to be a special talent - it is a legitimate avenue for those who are able. As noted earlier, Long Anai was declared by the Indonesian government as a Desa Kebudayaan (a Cultural Village). What that has meant is that there have been governmental efforts and incentives to keep Kenyah arts alive there. These include wood carving, music, dancing, boatmaking and comedy.

There are regular Kenyah dance performances shown on Facebook, with men as active in these performances as women. Kenyah men's dancing involves a great deal of alternately slow and fast movements, usually with bent knees and exaggerated eye movements. The male dancers still imitate both hunters and the hunted, wielding shields and bush knives and wearing animal skins, with headdresses made of hornbill feathers. ${ }^{60}$ They demonstrate their agility, grace and strength.

I was not going to be able to visit one man, Gun, who had been a child in the household where I lived in 1979-1980. We were both disappointed, so one of his relatives called him on the cell phone, while listening to another man, Rinto, play the haunting music of the sampe' (a Kenyah 'guitar'). Both these men were recognized as excellent performers, and while Rinto provided the music, Gun performed a Kenyah dance for us, visible on the tiny cell phone.

Rinto was interested in all the arts and felt that he might have inherited the spirit of Pelibut, the Long Segar headman who'd been talented in so many ways, artistic and otherwise. As before, the Long Segar community selects a young man who provides leadership to the youth. He organizes events, encourages them to dance and participate in sports and community life. Rinto is that leader. When my Long Segar family wanted to dress me up in Long Segar traditional attire, he was recognized as something of an expert in how to put all the pieces together (headgear, beads, hat, vest, skirt and hornbill feather hand decorations) appropriately. He bewailed the loss of beadlore (Colfer and Pelibut 2001), cultural meanings of specific designs and other traditional knowledge that has been or is being lost.

The arts of comedy and storytelling also remain alive and well. Pierce's older half brother, Dinis, can hold a Long Anai crowd enthralled for hours by the 
tales he tells, a talent that has long been admired-closely linked with the harp string for public speaking. His ability to keep an audience laughing until the wee hours of the morning ensures his popularity. Pierce was told, "Aside from being a courageous fighter, great hunter and fisherman, he is the best entertainer in the village". Another relative, Pierce's cousin, Libang, like Rinto in Long Segar, plays the sampe'. Libang is sent to various cultural expositions and thereby brings pride to the village by promoting and preserving traditional Dayak arts.

\section{Kenyah summary}

Men's expedition-making harp string has largely disappeared and their provisioning harp string has, as a result, changed dramatically as well. Men's perceived need for strength, courage and potential violence as protectors of family and village lands has re-emerged, reactivating harp strings that were more dominant during headhunting days of old.

Men's emphases on sexuality, rhetoric and politics and leadership remain strong, as does the arts harp string. People, including men, still share any visible abundance within their group. Land tenure issues have become still more worrying as people continue to lose access to their traditional areas. One enduring feature is the comparative equity and mutual respect evidenced in relations between men and women in daily life.

\section{Conclusions}

From a people-and-forests standpoint, these contexts represent three very different trends.

- The forests of upstate New York, where I now live, are growing back as the population empties out and people move to cities in search of economic opportunities. Corn fields and dairy farms revert to forests, adversely affected more by an over-abundance of deer than by human activity.

- The forests of Bushler Bay have been maintained by taking away local livelihoods (or at least requiring a major shift in emphasis), while protecting the habitat for endangered species — with major demographic and cultural shifts a result.

- The forests of Long Segar and Long Anai have been decimated, replaced by hundreds of hectares of oil palm with only small patches of regrowing forest, tiny swiddens and smallholder plots (increasingly mostly oil palm) remaining near rivers - a process to which local people have adapted amazingly resiliently alongside their mixed feelings of loss and gratitude.

In my corner of New York State and in Bushler Bay the polarized traditional imaginings of masculinity and femininity show signs of moderating, as a more muted version of gender difference-consistent with changing global 
norms-grows. In Kalimantan, where gender was muted in the 1970s, stronger differentiation, emphasizing and building on the greater physical strength of men, is encouraged by the growing insecurity of land tenure and the 'invasion' of other ethnic groups, some more powerful, whose systems are characterized by narratives of women's inferiority. Despite these worrying trends, relations between men and women continue to be comparatively equitable there. ${ }^{61}$

\section{Notes}

1 Pierce, my Kenyah-American son, participated in the fieldwork, collecting and recording stories in Long Anai. Erlita performed the statistical analyses in the third section of this chapter and prepared the figures.

2 E.g., the Convention on the Elimination of all forms of Discrimination Against Women (CEDAW), ratified by 189 states in 1981; The International Labour Organization (ILO) Policy on Gender Equality and Mainstreaming since 1999 (www.ilo.org/gender/langen/index.htm, accessed 1 May 2019); the Millennium Development Goals from 2000, and the Sustainable Development Goals since 2015; the World Health Organization (WHO) global plan of action to address violence against women and children (www. who.int/news-room/fact-sheets/detail/violence-against-women; accessed 1 May 2019); the populist 'me-too' movement; the Global Environment Facility (GEF) Policy on Gender Equality in 2017 (www.thegef.org/news/new-policy-gender-equality-gef; accessed 1 May 2019), and more.

3 "No person in the United States shall, on the basis of sex, be excluded from participation in, be denied the benefits of, or be subjected to discrimination under any education programme or activity receiving Federal financial assistance" (https://www2.ed.gov/ about/offices/list/ocr/docs/tix_dis.html, accessed 2 May 2019).

4 My father, when asked to extend his contract to continue teaching as a visiting scholar in Dubai in the late 1980s, negotiated the right to arrive late for the term, so that he could watch the Superbowl in the US.

5 For the first 25 years of our marriage, we had household help (discussed in Chapter 6), so neither of us performed these tasks.

6 Prior to COVID-19.

7 The amounts paid for this household labour are nowhere near as inequitable as in international contexts. Many here pay $\$ 20-\$ 40 /$ hour. If such employers make $\$ 100,000 /$ year, their hourly rate would be $\$ 47 /$ hour before taxes. Even if incomes are higherwhich some are-the divergence from the wages they pay workers is still far less than in the Indonesian examples in Chapter 6.

8 These two are 'Third Culture Kids' (Pollock and Reken 2001), as am I.

9 Remembering that the rural New York example is a ten-minute drive from Cornell University, that my social circle reflects that proximity, and is quite different from the surrounding countryside where Donald Trump and his political and social attitudes dominate.

10 Given the smaller number of older American men compared to older American women, demographically, combined with American informal age-grading (Colfer 1977) Hatch's (2000) comments may have relevance:

Other studies ... provide modest support for the thesis that women have greater economic and political power in low sex ratio societies (low numbers of men relative to women) than in high sex ratio societies.

11 Colfer, Cerveny, and Hummel (2019) and Colfer (2018) provide fuller details of these and other results from this study.

12 I did not see the many political signs expressing support for President Trump that I regularly see in rural upstate New York, and only one man expressed his commitment to Trump and his politics to me, face to face. 
13 "In-migration that occurs in a place because people are drawn to its natural and social features" (Charnley, McLain, and Donoghue 2008, p. 744).

14 All names are pseudonyms.

15 This refers to the Local-Public Employee social structural distinction (see Chapter 3).

16 Colfer and Colfer (1979).

17 'Pecker' is American slang for penis.

18 See Buttolph et al. (2006) for an assessment of changes in this community from 1994-2003.

19 Protection of the spotted owl, and later the marbled murrelet, was the immediate spur for a great deal of pro-environmental action. A few months before I arrived in 2017, a restaurant called Loggers Landing had closed. It had advertised "spotted owl soup" on the menu; in earlier times, pro-logger folk sported T-shirts that said, "Save a Logger; Kill a Spotted Owl".

20 Factual correction: To my knowledge there had been no mill in or near Bushler Bay for at least half a century.

21 In most of this book, I include Hood View in Bushler Bay, as most social patterns were similar.

22 Based on interviews with six mostly elderly individuals knowledgeable about the communities.

23 Proximity, pre-existing rights to forests, dependence on forests, poverty, local knowledge, culture/forest link and power deficit.

24 This pebble distribution tool was conducted in three mixed-gender group discussions, and with six women and three men individually. The emphasis on the elderly is an artefact of the availability of interviewees, but also reflects their demographic predominance.

25 Salal, brush, etc.; shellfish/fish; berries; firewood, poles, etc.; Christmas trees, wreaths, etc.; mushrooms; and animals/game. We interviewed two groups (aged $>50$ in Bushler Bay) and eight individuals, totaling 22 respondents. Half the individual respondents were $<50 ; 14$ were women, eight men.

26 Jackson (2001) concludes that performances of masculinity are age-specific, using examples from Kerala, India (pp. 5-6). See also e.g., Bribiescas 2016; Hatch 2000; Varley and Blasco 2001, on men and aging, from very different perspectives.

27 Tom was recommended to me by a long-resident, educated woman friend whom I'd known in our youths, as an interesting and opinionated man whom she liked but with whom she also often disagreed.

28 Cornwall (2016) notes that "Standing like a man [in Sierra Leone] . . . is also about being able to enable women's consumption of consumer goods, in a context where romance and finance are intimately interwoven" (p. 19); or Hayns 2016: "One dominating conception of masculinity in Morocco (and, of course, elsewhere) is that men-if they are indeed men-must make money and with it provide women, usually their wife or girlfriend, with material subsistence" (p. 105).

29 This symbolism is nothing new or unique to Bushler Bay: Remember my first husband's desire for a pickup truck in 1972 or watch the Dodge Ram ads on TV today. There is an F150 sandwich on the menu at the newer, more yuppy café in Bushler Bay. When my husband and I take breakfast at a rural diner in upstate New York (the equivalent of Bushler Bay's Local lifestyle), the pickups out-number the sedans many times over, with Subarus and Priuses identifying their drivers as outsiders, alien. That these trucks are American-made is not irrelevant either in Trump's America (though Trump's politics are not as popular in rural western Washington as in upstate New York).

30 I discovered Dick, through a friend of a friend in Portland, Oregon, who had used his construction services for her home on nearby Whidby Island. I imagined this would provide a new and different entrée to the community.

31 I'd known Harry marginally in the 1970s, but he was recommended by a Local woman I knew better, because of his knowledge of the brush industry (see https://products. kitsapsun.com/archive/2000/11-23/0002_brush_picking_-_the_silent_indust.html).

32 These folks identified as non-American do not live locally. They are reportedly brought in, typically contracted by bigger businesses, by the busload. Davis et al. (2020) note 
that the USFS often hires immigrants for labour-intensive tasks in the American West. Charnley et al. (2018) found that

on Washington's Olympic Peninsula-a focal point for the Northwest's floral greens industry - the harvester workforce was originally Euro-American, but shifted in the late 1970s and early 1980s to being dominated by refugees from Southeast Asia, then shifted again in the late 1980s to become dominated by immigrants from Mexico and Central America (McLain and Lynch 2010). Asians are also active participants in commercial wild mushroom harvesting, particularly matsutake (Tricholoma magnivelare).

(Charnley et al. 2018, p. 827)

33 One unemployed Local man of $~ 50$, working as a volunteer fireman, told of the patch of mushrooms he had found and delighted in keeping secret (notes, 30 May 2017). Another, a retired Public Employee who avoided contact with the community, regretted the loss of the forest in which he had habitually hunted mushrooms. It had disappeared when a private company logged the land adjacent to his property in 2016 (notes, 26 May 2017).

34 Or the situation described by Reed (2003) where "some women who were interviewed [on nearby Vancouver Island in 1997] chose not to risk challenging the 'manliness' of their partner by taking a job" (p. 384).

35 He did not give the impression, however, of having 'lost' his masculinity in the way described by Vera-Sanso (2016):

By taking the long view, we can see that in South India men typically follow a trajectory in which they attempt to achieve, and sustain, an adult masculinity, based on a socially enforced role as provider and head of the family, eventually declining into a feminized status as an aged dependent.

(pp. 82-83)

36 Although not stressed explicitly in the cases presented, courage came up in other interviews, e.g., one with a long-time firefighter produced the following response, among other courage-related remarks: "I asked if he felt fear in the forest. He said 'no, I've been chased by a moose, and been near grizzlies, but such experiences are part of the mystique"" (notes, 30 May 2017).

37 Fearing Cornell's IRB (Internal Review Board), I failed to request permission to engage with high school students and was thus precluded from interviewing those under 18 years of age, an error of judgment on my part. I also encountered greater reluctance in the school than in any other institution, perhaps due to rumours and the displeasure of one or two community members with the contents of my earlier studies, though legalities about dealing with minors may also have been the main issue.

38 Long Anai is a daughter village of Long Segar, located a few hours south of Samarinda. Long Segar residents began establishing it after the 1983 El Niño.

39 The Indonesian government required that an Indonesian conduct the interviews. In Long Anai, Tamen Loren and Pesuyang (a Kenyah man and woman in their 40s) conducted the interviews; in Long Segar, Dorkas and Erni (two Kenyah women in their 20s) did so.

40 The Kenyah change their names regularly, with all of them adopting a new name beginning with 'P' or 'Pe' when they become grandparents.

41 "Kalimantan's oil palm plantations have expanded rapidly over the last decades, covering a total area of $13,000 \mathrm{~km}^{2}$ (in 1,073 villages) in 2000 , tripling to $40,000 \mathrm{~km}^{2}$ (in 1,980 villages) in 2015" (Santika et al. 2019, p. 108).

42 This land is part of Indonesia's Forest Estate, and thus the government has the legal right to manage it; however, local people also consider the land to be theirs, according to their traditional land tenure system (land belongs to the person who first cleared the primary forest; see Marfo et al. 2010, for discussion of the Long Segar and Sitiung tenure situations). 
43 A Long Anai resident posted a video on Facebook (December 2019) of Long Anai men armed with bush knives and spears angrily demonstrating at a new mining operation on land the men considered their own. The Indonesian military was in evidence as well.

44 Siscawati (2020) also found that men make fewer expeditions in Lampung Province, though she attributes this to the effects of the government's tenure reform effortsspecifically, Hutan Kemasyarakatan (HKm, community-managed forests) and Hutan Tanaman Rakyat (HTR, community-based plantation forests), which have strengthened tenure security, exactly the opposite of trends in Long Segar. These programmes, not implemented in Long Segar, appear also to have enhanced women's empowerment and involvement in formal forest management in Lampung. See Colfer, Monterroso, and Ihalainen (2020, in press) or Elmhirst, Siscawati, and Colfer (2016) for discussions of the impacts of these landscape changes, new tenure regimes and new powerful actors on women in Long Segar and Long Anai.

45 See Chapter 4.

46 The conclusions of Santika et al. (2019) appear to apply to our study communities as well:

We found an overall increase in basic, physical and financial indicators of well-being between 2000 and 2014, both in villages with oil palm plantation developments and those without such developments across Kalimantan between 2000 and 2014 . . Conversely, there was an overall decline in social and environmental measures of well-being . . .

Ironically, those with oil palm development showed slower increases in the first measures and faster declines in the latter measures.

47 In the 1980 survey, in both remote Long Ampung and Long Segar, 56\% of the women reported attending meetings (from 'rarely' to 'always'; 'sometimes' being the mode, $40 \%$ in Long Ampung and 43\% in Long Segar). Although I did not ask then whether the women spoke at community meetings, I observed that they rarely did.

48 Evidence supporting this local observation is available from remote sensing. The rate of forest loss declined precipitously after 2016, and new plantation development (thus land clearing) began declining after 2012 (Gaveau et al. 2018).

49 One survey question, "Did anyone tell you what to do today? If yes, who told you?" ( $A$ 'un dulu dia' ca cuk Iko' uyan inu tau ini? Bek ya, ee' ya' cu' iko'?) was intended to ascertain who was telling whom what to do, but in the Long Anai case is probably more of a proxy for wage employment. There, this was typically interpreted to refer to what happened at work; in Long Segar it was interpreted more broadly, including as originally intended. One hundred percent of Long Anai women respondents indicated they'd been told what to do that day by 'folks working together'; for men, 78\%. In Long Segar, where there was a greater likelihood of the traditional shared work parties (Indonesian: gotong royong; Kenyah: pemong gayeng) and fewer individuals formally employed, the figures were $16 \%$ and $26 \%$, respectively. For comparison, a similar question was asked in Long Ampung and Long Segar in 1980: "Of the 15\% in Long Ampung and the 20\% in Long Segar who responded affirmatively, almost none mentioned their husband or any other man as the person who had assigned the task" (Colfer 1985a, p. 199). In these new data, men and women in both communities commonly told each other what to do with no significant gender differentiation (2019 survey).

50 The question of land rights in Indonesia is extraordinarily complex. For decades, the claims of rural people living in forests were not recognized at all. In recent years, the central government has developed several social forestry schemes, which are experimentally implemented in some areas. This CIFOR video (Securing Customary Rights to Forests in Maluku Province, Indonesia) outlines some encouraging discussions recently underway about forest tenure in Maluku, where communities want formalization of their traditional systems and full management rights rather than a shared system. Or see 
Fisher et al. (2017) for an analysis of a lengthy attempt to bring together the interests of a traditional community in South Sulawesi with those of formal forest managers, with varying success.

51 This question in 1980 was "Did you help decide how to spend the money you got from selling rice last year?" in Long Segar and "Did you help decide how to use last year's rice?" in Long Ampung (where money had little use). In both these communities, 64\% of the women reported helping decide.

52 This section particularly has benefitted from the insights of Andrew Balan Pierce (half Kenyah, aged 37). His interactions with the Kenyah in Long Anai brought forth much more discussion about courage, strength and forest-based skills than did my own interactions.

53 Sadly, that study involved no men respondents.

54 See Manurung (2019), for similar stories about Sumatra's Orang Rimba.

55 The existence of such urban Dayaks represents another difference from the 1980 context, when almost no Dayaks could be considered urban.

56 Resorting to such threatened violence was not new. The people of Long Anai said they "threatened the HTI [industrial timber concession] workers with blowpipes and drove them away four months ago" (journal, 28 March 1996). The December 2019 Facebook video of such a confrontation has already been mentioned.

57 In Long Segar, Colfer's fictive brother's son had gone hunting in the forest. Thinking to have a stronger shot, he had rammed multiple bullets down the barrel of his gun, and it had indeed exploded in his face, blinding him for life (notes, 16 March 2019).

58 A somewhat similar conflict was the original impetus of the deadly Madurese-Dayak conflict in West Kalimantan:

On 29 December 1996, at a pop music concert in Ledo, Sambas District, West Kalimantan, two Dayak youths were stabbed by a group of Madurese seeking revenge for being humiliated at a previous concert after 'bothering' a Dayak girl.

(Peluso 2008, p. 49)

59 A quick search of my 2017 notes on Bushler Bay, for 'sex' turned up no entries and for 'love', 50 entries, the vast majority of which were love of the environment. Ten percent were love of animals, $8 \%$ love of work, with another $10 \%$ scattered among four topics. The only love relating to humans was mothers' love for their children (4\%). All this is interesting in light of recent articles on a 'sex recession' in the US.

60 Roberts (2011) describes the attitudes of three Native Americans from the Plains about dancing:

These three men . . . can be said to represent three different personal perspectives about competition, war, and masculinity in powwows. Ira respects competition in powwows, and participates in competitive powwows, but makes a personal choice not to enter the contests. Jim is drawn mainly to the spiritual aspects of dancing and also is grateful for the money he might win in competitions. Doug . . competes because of the communally spiritual rewards of dancing. He ... describes himself significantly as 'a modern day warrior'.

(p. 155, italics in original)

See Spiller (2010) for Sundanese men's attitudes toward and performance of dance.

61 Siscawati's (2020) observation that gender norms had not changed much with the advent of formal social forestry programmes in Lampung Province, in this case remaining inequitable, also speaks to the deep and enduring nature of gender relations.

\section{References}

Anderson, Eric. 2009. Inclusive Masculinity. New York: Routledge.

Bari, Judi. 1994. Timber Wars. Monroe, ME: Common Courage Press. 
Bribiescas, Richard G. 2016. How Men Age: What Evolution Reveals about Male Health and Mortality. Princeton, NJ: Princeton University Press.

Buttolph, Lita P., William Kay, Susan Charnley, Cassandra Moseley, and Ellen M. Donoghue. 2006. "Northwest Forest Plan-The First 10 Years (1994-2003): Socioeconomic Monitoring of the Olympic National Forest and Three Local Communities." Pacific Northwest Research Station General Technical Report, PNW-GTR-679:84. Portland, Oregon.

Charnley, Susan, Delilah Jaworski, Heidi Huber-Stearns, Eric M. White, Elisabeth Grinspoon, Rebecca J. McLain, and Lee Cerveny. 2018. "Chapter 10-Environmental Justice, Low-Income and Minority Populations, and Forest Management in the Northwest Forest Plan Area." In Synthesis of Science to Inform Land Management Within the Northwest Forest Plan Area (General Technical Report PNW-GTR-966), edited by T. A. Spies, P. A. Stine, R. Gravenmier, J. W. Long, and M. J. Reilly, 809-849. Portland, OR: US Forest Service.

Charnley, Susan, Rebecca J. McLain, and Ellen M. Donoghue. 2008. "Forest Management Policy, Amenity Migration, and Community Well-Being in the American West: Reflections from the Northwest Forest Plan." Human Ecology 36:743-761. https://doi.org/10.1007/s10745-008-9192-3.

Colfer, A. Michael, and Carol J. Pierce Colfer. 1979. Big Money, Small Change: Cultural Paradigms in an American Village. Cambridge, MA: Abt Associates.

Colfer, Carol J. Pierce. 1977. Women's Communication and Family Planning in Rural America: The Case of Bushler Bay. Edited by D. Lawrence Kincaid. Vol. 4, Case Studies in Family Planning. Honolulu, HI: EWCI (Case Study \#4; reprinted 1978).

Colfer, Carol J. Pierce. 1985a. "Female Status and Action in Two Dayak Communities." In Women in Asia and the Pacific: Toward an East-West Dialogue, edited by M. J. Goodman, 183-214. Honolulu: University of Hawaii Press.

Colfer, Carol J. Pierce. 1985b. "On Circular Migration: From the Distaff Side." In Labour Circulation and the Labour Process, edited by G. Standing, 219-251. London: Croom Helm.

Colfer, Carol J. Pierce. 2018. "Before and After the 'Timber Wars': Context, Change and Potential Collaboration on the Olympic Peninsula." Humboldt Journal of Social Relations 40:137-162.

Colfer, Carol J. Pierce, Lee Cerveny, and Susan Stevens Hummel. 2019. "Using Rapid Rural Appraisal Tools to Explore Gender and Forests in the Global North." Human Organization 78 (1):12-27.

Colfer, Carol J. Pierce, Iliana Monterroso, and Markus Ihalainen. (2020, in press). "Understanding Gender Dynamics in the Context of Rural Transformation Processes: A Case from East Kalimantan." CIFOR Occasional Paper.

Colfer, Carol J. Pierce, and Juk Along Pelibut. 2001. "Beadlore of the Uma' Jalan Kenyah." The Sarawak Museum Journal 77 (new series) (LVI):29-35.

Colfer, Carol J. Pierce, and Herwasono Soedjito. 2003. "Food, Forest, and Fields in a Bornean Rain Forest: Toward Appropriate Agroforestry Development." In Borneo in Transition: People, Forests, Conservation and Development, edited by Christine Padoch and Nancy Peluso, 215-223. Kuala Lumpur: Oxford University Press. Original edition, 1996.

Connell, R. W. 1995. Masculinity. Berkeley, CA: University of California Press.

Cornwall, Andrea. 2016. "Introduction: Masculinities under Neoliberalism." In Masculinities under Neoliberalism, edited by Andrea Cornwall, Frank G. Karioris, and Nancy Lindisfarne, 1-28. London: Zed Books.

Dark, A. 1997. "Landscape and Politics on the Olympic Peninsula: Social Agendas and Contested Practices in Scientific Forestry." Journal of Political Ecology 4 (1):1-25. 
Davis, Emily Jane, Reem Hajjar, Susan Charnley, Cassandra Moseley, Kendra Wendel, and Meredith Jacobson. 2020. "Community-based Forestry on Federal Lands in the Western United States: A Synthesis and Call for Renewed Research.” Forest Policy and Economics 111:1-12.

Elias, Marlène, Netsayi Mudege, Diana E. Lopez, Dina Najjar, Vongai Kandiwa, Joyce Luis, Jummai Yila, Amare Tegbaru, Gaya Ibrahim, Lone Badstue, Esther NjugunaMungai, and Abderahim Bentaibi. 2018. "Gendered Aspirations and Occupations Among Rural Youth, in Agriculture and Beyond: A Cross-regional Perspective." Journal of Gender, Agriculture and Food Security 3 (1):82-107.

Elmhirst, Rebecca, Mia Siscawati, and Carol J. Pierce Colfer. 2016. "Revisiting Gender and Forestry in Long Segar, East Kalimantan: Oil Palm and Divided Aspirations." In Gender and Forestry: Climate Change, Tenure, Value Chains, and Emerging Issues, edited by Carol J. Pierce Colfer, Bimbika Sijapati Basnett, and Marléne Elias, 300-317. London: Earthscan/CIFOR.

Fisher, Micah R., Timothy Workman, Agus Mulyana, Balang Institute, Moira Moeliono, E. Linda Yuliani, Carol J. Pierce Colfer, and Urban El Fatih Bani Adam. 2017. "Striving for PAR Excellence in Land Use Planning: Multi-Stakeholder Collaboration on Customary Forest Recognition in Bulukumba, South Sulawesi." Land Use Policy. http:// dx.doi.org/10.1016/j.landusepol.2017.09.057.

Gaveau, David L. A., Bruno Locatelli, Mohammad A. Salim, Husna Yaen, Pablo Pacheco, and Douglas Sheil. 2018. "Rise and Fall of Forest Loss and Industrial Plantations in Borneo (2000-2017)." Conservation Letters 8:1-8. wileyonlinelibrary.com/journal/conl.

Hatch, Laurie Russell. 2000. Beyond Gender Differences: Adaptation to Aging in Life Course Perspective. London: Routledge.

Hayns, Joe. 2016. "Desperate Markets and Desperate Masculinities in Morocco." In Masculinities under Neoliberalism, edited by Andrea Cornwall, Frank G. Karioris, and Nancy Lindisfarne, 99-110. London: Zed Books.

Jackson, Cecile. 2001. "Men at Work." In Men at Work: Labour, Masculinities, Development, edited by Cecile Jackson, 1-22. Portland, OR: Frank Cass, with EADI (European Association of Development Research and Training Institutes, Bonn).

Kirschner, Annabel R. 2010. "Understanding Poverty and Unemployment on the Olympic Peninsula after the Spotted Owl." The Social Science Journal 47 (2):344-358.

Manurung, Butet. 2019. "Normalising' the Orang Rimba." In Contentious Belonging: The Place of Minorities in Indonesia, edited by Greg Fealy and Ronit Ricci, 232-251. Singapore: ISEAS Yusof Ishak Institute.

Marfo, Emmanuel, Carol J. Pierce Colfer, Bocar Kante, and Silvel Elias. 2010. "From Discourse to Policy: The Practical Interface of Statutory and Customary Land and Forest Rights." In Forest for People: Community Rights and Forest Tenure Reform, edited by Anne Larson, Deborah Barry, Ganga Ram Dahal, and Carol J. Pierce Colfer, 69-89. London: Earthscan/CIFOR.

McLain, R. J., and Lynch, K. 2010. "Managing Floral Greens in a Globalized Economy: Resource Tenure, Labour Relations, and Immigration Policy in the Pacific Northwest, USA." In Wild Product Governance: Finding Policies that Work for Nontimber Forest Products, edited by S. A. Laird, R. J. McLain, and R. P. Wynberg, 265-286. Washington, DC: Earthscan.

Nader, Laura. 1972. Up the Anthropologist: Perspectives Gained From Studying Up. Washington, DC: US Department of Health, Education and Welfare.

Peluso, Nancy Lee. 2008. "A Political Ecology of Violence and Territory in West Kalimantan." Asia Pacific Viewpoint 49 (1):48-67. 
Petesch, Patti, Renee Bullock, Shelley Feldman, Lone Badstue, Anne Rietveld, Wenda Bauchspies, Adelbertus Kamanzi, Amare Tegbaru, and Jummai Yila. 2018. "Local Normative Climate Shaping Agency and Agricultural Livelihoods in Sub-Saharan Africa." Journal of Gender, Agriculture and Food Security 3 (1):108-130.

Pollock, David C., and Ruth Van Reken. 2001. Third Culture Kids: The Experience of Growing Up Among Worlds. Boston: Nicholas Brealey Publishing.

Reed, Maureen G. 2003. "Marginality and Gender at Work in Forestry Communities of British Columbia, Canada." Journal of Rural Studies 19:373-389.

Roberts, Kathleen Glenister. 2011. "War, Masculinity, and Native Americans." In Global Masculinities and Manhood, edited by Ronald L. Jackson II and Murali Balaji, 141-160. Urbana, IL: University of Illinois Press.

Santika, Truly, Kerrie A. Wilson, Sugeng Budiharta, Elizabeth A. Law, Tun Min Poh, Marc Ancrenaz, Matthew J. Struebig, and Erik Meijaard. 2019. "Does Oil Palm Agriculture Help Alleviate Poverty? A Multidimensional Counterfactual Assessment of Oil Palm Development in Indonesia." World Development 120:105-117.

"Securing Customary Rights to Forests in Maluku Province, Indonesia". 2020. Bogor, Indonesia: CIFOR. www.cifor.org/gcs-tenure/.

Siscawati, Mia. 2020. "Gender and Forest Tenure Reform in Indonesia." CIFOR Working Paper 258, Bogor, Indonesia.

Spiller, Henry. 2010. Erotic Triangles: Sundanese Dance and Masculinity in West Java. Chicago, IL: University of Chicago Press.

Tsing, A. L. 2015. The Mushroom at the End of the World: On the Possibility of Life in Capitalist Ruins. Princeton, NJ: Princeton University Press.

Varley, Ann, and Maribel Blasco. 2001. "Exiled to the Home: Masculinity and Ageing in Urban Mexico." In Men at Work: Labour, Masculinities, Development, edited by Cecile Jackson, 115-138. Portland, OR: Frank Cass with EADI (European Association of Development Research and Training Institutes, Bonn).

Vera-Sanso, Penny. 2016. "Taking the Long View: Attaining and Sustaining Masculinity Across the Life Course in South India." In Masculinities Under Neoliberalism, edited by Andrea Cornwall, Frank G. Karioris, and Nancy Lindisfarne, 80-98. London: Zed Books. 